\title{
Novel Invasive and Noninvasive Cardiac-Specific Biomarkers in Obesity and Cardiovascular Diseases
}

\author{
Rajesh Parsanathan, PhD and Sushil K. Jain, PhD
}

\begin{abstract}
Cardiovascular disease (CVD) is the leading cause of fatality and disability worldwide regardless of gender. Obesity has reached epidemic proportions in population across different regions. According to epidemiological studies, CVD risk markers in childhood obesity are one of the significant risk factors for adulthood CVD, but have received disproportionally little attention. This review has examined the evidence for the presence of traditional cardiac biomarkers (nonspecific; lactate dehydrogenase, alanine aminotransferase, aspartate aminotransferase, creatine kinase, myoglobulin, glycogen phosphorylase isoenzyme BB, myosin light chains, ST2, and ischemia-modified albumin) and novel emerging cardiac-specific biomarkers (cardiac troponins, natriuretic peptides, heart-type fatty acid-binding protein, and miRNAs). Besides, noninvasive anatomical and electrophysiological markers (carotid intima-media thickness, coronary artery calcification, and heart rate variability) in CVDs and obesity are also discussed. Modifiable and nonmodifiable risk factors associated with metabolic syndrome in the progression of CVD, such as obesity, diabetes, hypertension, dyslipidemia, oxidative stress, inflammation, and adipocytokines are also outlined. These underlying prognostic risk factors predict the onset of future microvascular and macrovascular complications. The understanding of invasive and noninvasive cardiac-specific biomarkers and the risk factors may yield valuable insights into the pathophysiology and prevention of CVD in a high-risk obese population at an early stage.
\end{abstract}

Keywords: cardiovascular diseases, cardiac-specific biomarkers, cardiac troponins, heart rate variability, natriuretic peptides, childhood obesity

\section{Introduction}

$\mathrm{O}$ BESITY IS BECOMING a global epidemic in both children and adults. It is associated with an increased risk of morbidity and mortality as well as reduced life expectancy; with numerous comorbidities, such as cardiovascular diseases (CVDs), type 2 diabetes, and hypertension. Obesity is an independent risk factor for CVD, and CVD risks have also been documented in obese children. Excess reactive oxygen species (ROS) production plays a pivotal role in oxidative damage ${ }^{1}$ and may contribute to the onset and progression of these pathologies of CVDs ${ }^{1,2}$ (Fig. 1). Although an initiating factor is still elusive, development of CVD within all these tissues is a complicated cycle of lipid and glucose toxicity, which leads to the development of oxidative stress, chronic inflammation, and insulin resistance.
There are eight critical risk factors for heart disease and stroke that play a significant role in the progression of CVD according to The National Heart, Lung, and Blood Institute of the U.S. National Institutes of Health (Fig. 2). ${ }^{3}$ Along with nonmodifiable risk factors, such as age and family history, six of the factors are modifiable: the biological factors, including hypertension, diabetes, and abnormal lipid profile; and the lifestyle factors, including tobacco use, physical inactivity, and obesity. CVDs involve the cardiovascular system: the heart, blood vessels, and the circulatory system (Fig. 3). ${ }^{4}$ World Health Organization reports that the prevalence of CVD will double by 2020, passing HIV/AIDS infection and causing more than 20 million CVD-related deaths globally. ${ }^{4}$ CVD is the leading cause of fatality globally regardless of gender ${ }^{5}$ and accounts for $48 \%$ of noncommunicable diseases, ${ }^{3,6}$ although estimates predicted that $90 \%$ of CVD is avertable. ${ }^{7}$

Department of Pediatrics and Center for Cardiovascular Diseases and Sciences, Louisiana State University Health Sciences CenterShreveport, Shreveport, Louisiana. 


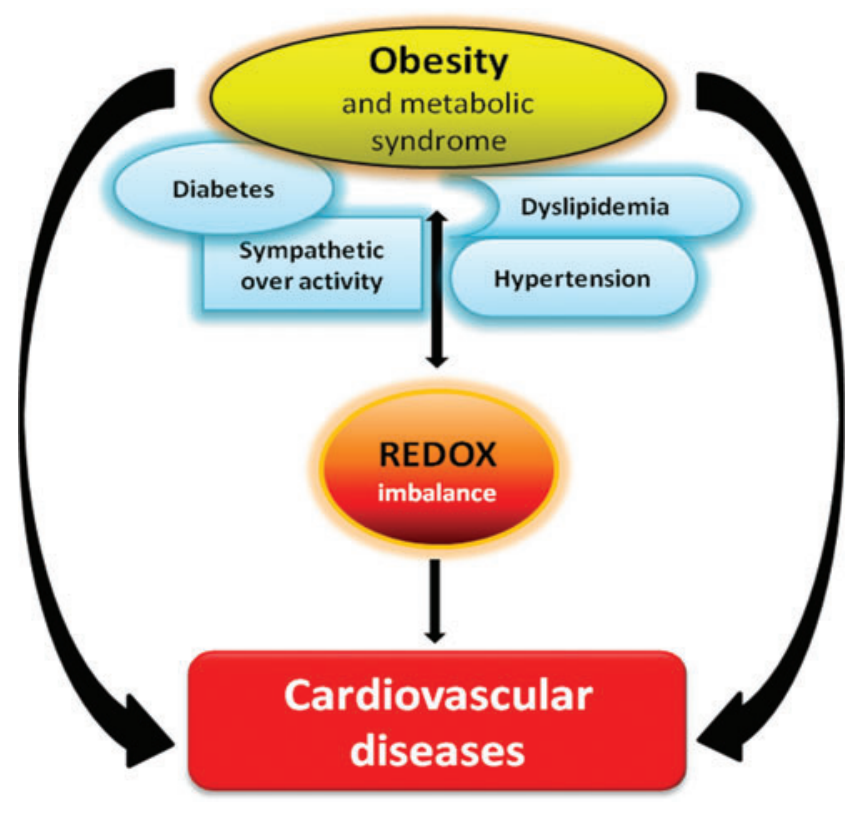

FIG. 1. The major modifiable risk factors-obesity and metabolic syndrome-redox imbalance essential predictors of CVD. CVD, cardiovascular disease. Color images are available online.

The pathological processes and risk factors of atherosclerosis have been shown to begin during early childhood. ${ }^{8}$ Among people with diabetes, CVD is the most lifethreatening complication; diabetic population showed the leading cause of cardiovascular-related death (2-4-fold higher incidence) than nondiabetics..$^{9-11}$

Visible abdominal obesity is a crucial sign of CVD along with the elevated levels of very low-density lipoprotein (LDL), triglycerides, and low levels of high-density lipoprotein cholesterol (HDL-C). ${ }^{12}$ Similarly, quantification of epicardial adipose tissue and assessment of coronary computed tomography (CT) angiography can establish a correlation between coronary artery disease $(\mathrm{CAD})^{13}$ and function as clinically essential biomarkers in acute coronary syndrome (ACS). ${ }^{14}$

Biomarkers are promising of tools for use in the overall management of the screening, diagnosis, and treatment of

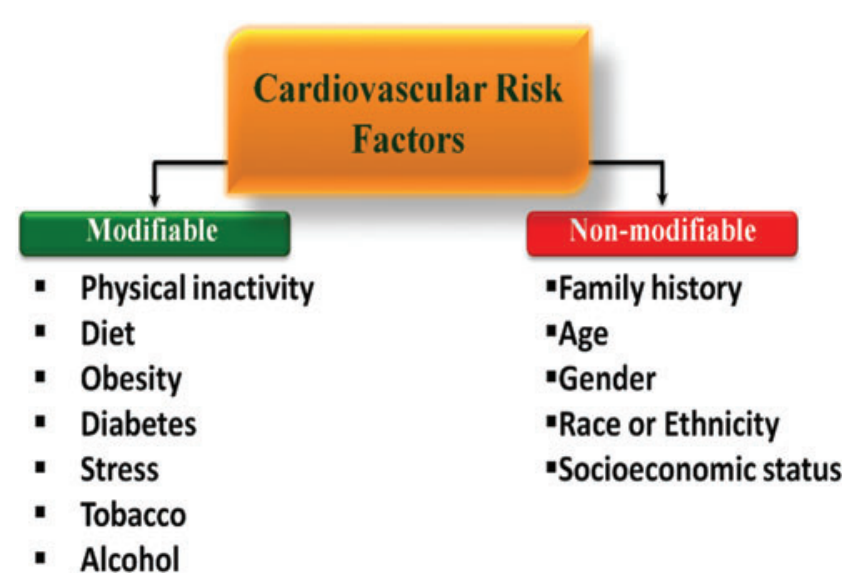

FIG. 2. Classification of modifiable and nonmodifiable cardiovascular risk factors. Color images are available online.

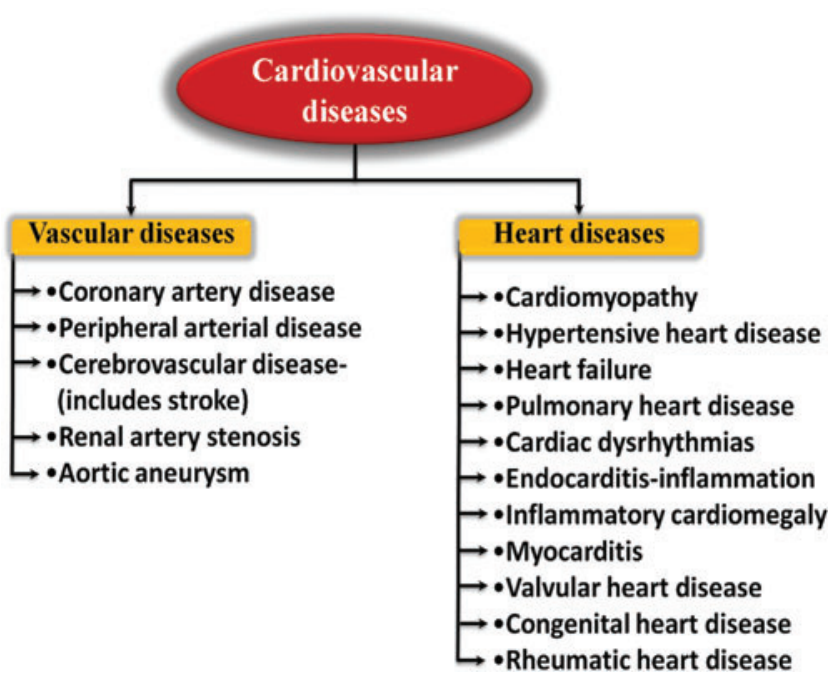

FIG. 3. Classification of CVDs involving in the blood vessels (vascular disease) and heart (heart disease). Color images are available online.

at-risk subjects/patients. ${ }^{15,16}$ This review has examined the evidence for the presence of traditional cardiac biomarkers [nonspecific; lactate dehydrogenase (LDH), alanine aminotransferase (ALT), aspartate aminotransferase (AST), creatine kinase $(\mathrm{CK})$, myoglobulin, glycogen phosphorylase isoenzyme BB (GPBB), myosin light chains, ST2, and ischemia-modified albumin (IMA)] and novel emerging cardiac-specific biomarkers [cardiac troponins (cTn), natriuretic peptides (NPs), heart-type fatty acid-binding protein (H-FABP), and miRNAs]. Besides, noninvasive anatomical and electrophysiological markers [carotid intima-media thickness (CIMT), coronary artery calcification (CAC), and heart rate variability (HRV)] in CVDs and obesity are also discussed. A timeline of the history of the development of cardiac biomarkers of myocardial injury, necrosis or ischemia, and hemodynamic stress and its sensitive assays/ biomarkers are summarized in Fig. $4 .^{17-38}$

The understanding of invasive and noninvasive cardiacspecific biomarkers and the risk factors may yield valuable insights into the pathophysiology and prevention of CVD in a high-risk obese population at an early stage.

\section{Risk Factors for CVD}

There are numerous risk factors associated with coronary heart disease (CHD) and stroke. A few risk factors, such as family history, cannot be modified, while other risk factors, such as high blood pressure, can be modified with treatment. Obesity, diabetes, sedentary lifestyle, and diet are modifiable risk factors (Fig. 2).

\section{Cardiovascular disorders risk in the young adolescent population}

CVD considered as a disease of adulthood, as mentioned above, the risk factors for CVD are present during childhood and persist into adulthood. Obese children have a higher chance to become obese adults. ${ }^{39}$ Severe health conditions in adult, including type 2 diabetes and heart disease are associated with and have a higher risk with obesity. ${ }^{40,41}$ Obese 


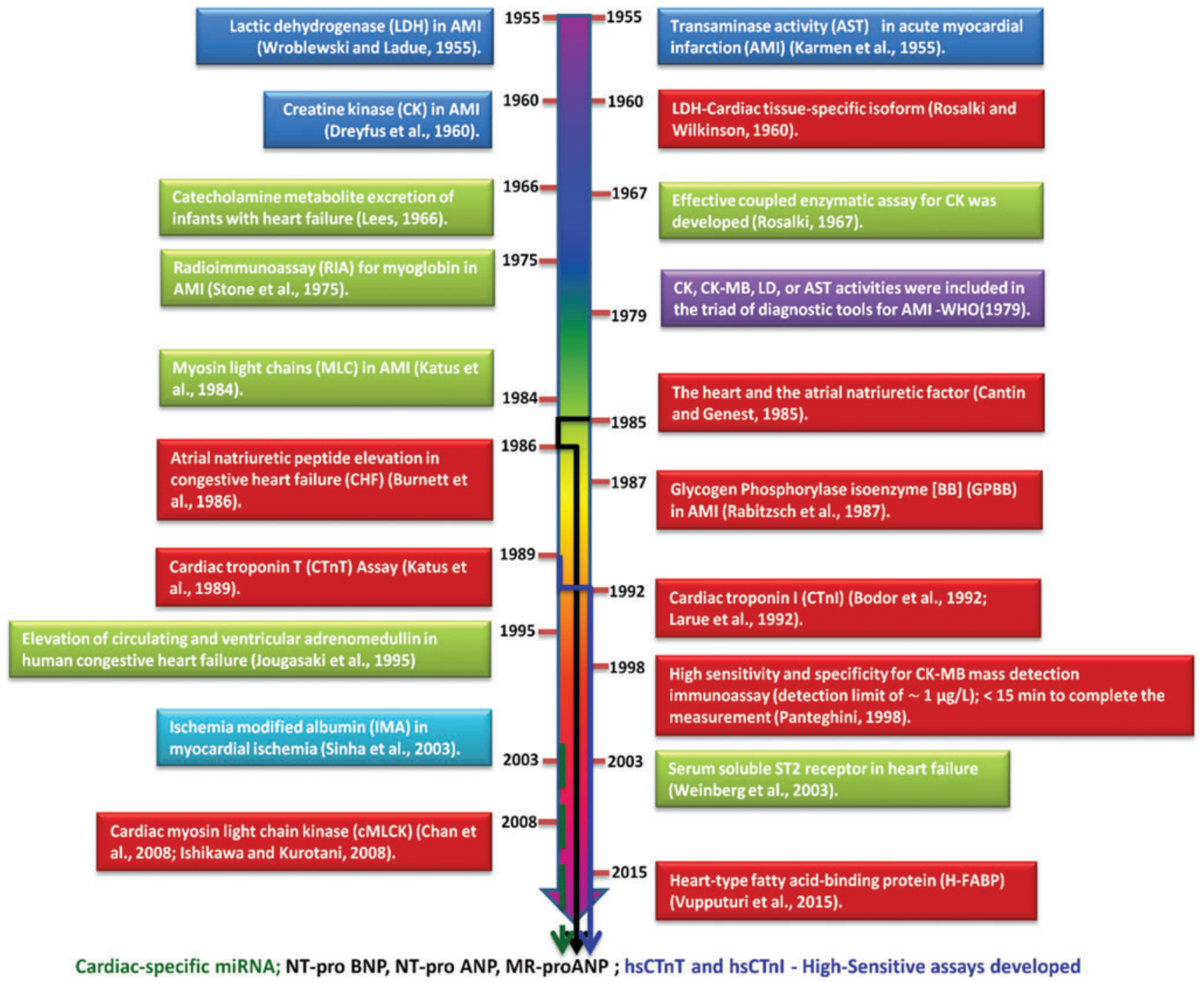

FIG. 4. The developmental timeline history of cardiac biomarkers of myocardial injury, necrosis or ischemia, and hemodynamic stress and its sensitive assays. Color images are available online.

children are more likely to experience severe obesity and disease risk factors in adulthood. ${ }^{42-44}$ Dietary modifications and therapeutic lifestyle changes may reduce obesity and its associated complications, ${ }^{45}$ which is essential because the upsurge in deskbound behavior in children and youth is an emerging risk factor for cardiometabolic disorders. ${ }^{46}$

Epidemiological studies show that atherosclerosis, the forerunner of CVD, initiates in childhood. Overweight adolescents ran a relatively higher risk end of mortality from $\mathrm{CHD}$, after 55 years of follow-up, independent of adult weight. ${ }^{47}$ Obese youths (7-9 years), majority having aortic intimal lesions and more than $50 \%$ of the right coronary arteries ${ }^{48}$ is shown in the Pathobiological Determinants of Atherosclerosis in Youth Study. Cardiovascular risks among adolescents are poorly understood. The increase in unattended risk factors and the obesity pandemic have created calculable cardiovascular disorder risk in the young adolescent population.

\section{Gender differences in obesity, diabetes, and CVDs}

CVD has traditionally been viewed as a male disease; however, the relative risks for diabetes, obesity, and hypertension morbidity and mortality, major risk factors for CVD, are higher for women. In the general population, obesity has adverse effects on most of the major CVD risk factors; however, despite these adverse effects on CVD risk factors and increasing the prevalence of CVD, the physiological disparities between the sexes likely contribute to differences in disease onset, susceptibility, and prevalence and treatment responses. ${ }^{49}$ In the United States, obesity affects more women ( $\sim 36 \%$ ) than men $(32 \%)$; as obesity is associated with a loss of cardioprotection, CVD occurs at an earlier age in obese women than in lean women. ${ }^{50}$ The cardioprotection generally observed in women $<55$ years of age is lost in the milieu of obesity and metabolic syndrome. ${ }^{51,52}$ Interestingly, obese women also develop more obesity-related conditions, such as hyperlipidemia, insulin resistance, and type 2 diabetes mellitus, than obese men, and these conditions are associated with more severe outcomes in women. ${ }^{51}$

\section{Metabolic syndrome may cause sympathetic overactivity and hypertension}

Obesity, a significant risk factor for diabetes and CVD, is associated with dysregulation of autonomic function and 
overactivity of the sympathetic nervous system (SNS) (Fig. 1), which may contribute to glucose intolerance and insulin resistance. ${ }^{53-58}$ Insulin acts on neurons in the arcuate nucleus of the hypothalamus and activates the sympathetic nerve. ${ }^{59}$ The sympathetic activity is also controlled by insulin action, which decreases during fasting and increases in response to raised insulin levels following a mixed meal/during a euglycemic hyperinsulinemic clamp. Sympathetic overactivity in obesity can also contribute to cardiac arrhythmia, left ventricular (LV) diastolic dysfunction, LV hypertrophy, and heart failure (HF). ${ }^{60}$ The degree of insulin resistance measured under obese conditions reflects autonomic dysfunction and is a predictor of CVD.

\section{Dyslipidemia and hypertension-related cardiovascular risks}

Dyslipidemia is a metabolic abnormality leading to a persistent increase in the plasmatic concentration of cholesterol and triglycerides (Fig. 1). All lipid-related abnormalities are responsible for cardiovascular mortality, fatal myocardial infarction (MI), and brain stroke. ${ }^{4}$ Pediatric groups prevalently suffer from diseases such as dyslipidemia/hyperlipidemia, atherosclerosis, familial hypercholesterolemia, hypertriglyceridemia, and diabetes. Physiological biomarkers are based on measuring the levels of critical components of lipid homeostasis, such as the triglyceride-to-HDL ratio, lipoprotein/cholesterol ratio, lipid/lipoprotein ratio, LDL cholesterol (LDL-C) level, HDL and apolipoprotein levels, lipoprotein and LTP ratio, sphingolipids, omega-3 Index, and ST2 level. ${ }^{61}$ Low levels of HDL-C independently contribute to CV risk and are associated with an increased risk of CHD, but HDL is protective against atherosclerosis. ${ }^{62}$

Hypertension accounts for an estimated 54\% of all strokes and $47 \%$ of all ischemic heart disease events worldwide. ${ }^{63}$ Hypertension is one of the most critical risk factors for almost all varieties of premature CVD ${ }^{64,65}$ including stroke, $\mathrm{CAD}, \mathrm{HF}$, atrial fibrillation $(\mathrm{AF}),{ }^{66}$ and peripheral vascular disease acquired over a lifetime; it is more common than dyslipidemia, diabetes, and cigarette smoking, which are the other major risk factors. The risk for both coronary disease and stroke increases progressively with incremental increases in blood pressure above $115 / 75 \mathrm{mmHg}$, as shown in numerous epidemiological studies. ${ }^{63}$

Hypertension, often combined with obesity and dyslipidemia, is one of the foremost essential predictors of $\mathrm{CVD}^{67,68}$ (Fig. 1). Childhood obesity, hypertension, and dyslipidemia are modifiable antecedents of adult CVD. ${ }^{69}$ Hypertension occurs in 3\%-5\% of children in the United States; among obese children, the percentage is much higher (up to $25 \%$ ). ${ }^{68}$ Hypertriglyceridemia and low high-density lipoprotein (HDL) cholesterol are the dyslipidemias most likely to occur in obese youths. ${ }^{69-73}$ Almost $17 \%$ of obese adolescents in the United States have abnormal non-HDL-C values; severe obesity correlates with high total cholesterol (10\% with overweight to $19 \%$ with class III obesity), low HDL-C ( $\leq 19 \%$ with class III obesity), and high triglycerides ( $29 \%$ with class III obesity) ${ }^{69,70,73}$ In addition to the conventional clinic-based risk factors used to predict preclinical CVD, lipid measurements and the hypertension status in obese youth may affect the independent prediction of adultonset CVD.

\section{Metabolic syndrome-oxidative stress, inflammation, and adipocytokines}

The metabolic syndrome is a common and complex disorder combining obesity, dyslipidemia, hypertension, and insulin resistance (Fig. 1). It is a primary risk factor for diabetes and CVD. ${ }^{74-76}$ Free radicals appear to be essential modulators of atherovascular disease in all stages of development and progression. ${ }^{77}$ Physiologically, they are signal transducers in cell communication and homeostasis, including vascular gene expression and cell interactions. ${ }^{78}$ Uncontrolled generation of free radicals leads later to disease. Oxidative stress may be a predictive marker for CVD. ${ }^{79}$ Obese LDL receptor-deficient mice were associated with increased oxidative stress and impaired HDL-associated antioxidant defense associated with accelerated atherosclerosis due to increased macrophage infiltration and accumulation of oxidized LDL in the aorta. ${ }^{80}$ Oxidative stress correlates with ventricular remodeling and progressive dilation leading to end-stage HF; further neuroendocrine system, ROS, and inflammatory cytokines are essential regulators of the remodeling process. ${ }^{79,81,82}$ The primary sources of CVD-ROS are mitochondrial NADPH oxidases (NOX), lypoxidases, and myeloperoxidases (MPOs). ${ }^{83} \mathrm{It}$ has been shown that increased renin/angiotensin/aldosterone system activity stimulates NADH/NOX ${ }^{84,85}$ The critical role of oxidative stress in cardiovascular pathophysiology has encouraged quantification of ROS as a promising biomarker reflecting the disease process. However, the transitory nature and short half-life confound in the measurements of ROS by standard approaches such as spin-trapping ${ }^{86}$ method. Different markers [isoprostanes, malondialdehyde, MPO, OxLDL, and oxidative protein post-translational modifications (nitrotyrosine, S-glutathionylation, S-sulfhydration)] are elevated in the presence of multiple CV risk factors. ${ }^{86-88}$

Epicardial and pericardial adipose tissues are local energy sources that facilitate the contractile activity of the heart by releasing fatty acids (lipolysis) under standard conditions. ${ }^{89-91}$ However, increased epicardial fat (EF) and pericardial fat are important risk factors for obesity-related cardiac dysfunction. ${ }^{91}$ Echocardiography, $\mathrm{CT}$, and magnetic resonance imaging have been used to evaluate $\mathrm{EF}$, but variations between methodologies limit the comparability between these modalities. ${ }^{92-94} \mathrm{EF}$ causes local inflammation and may have direct effects on coronary atherosclerosis.

Among the various adipocytokines, there has been considerable emphasis on leptin, adiponectin, and interleukin-6 (IL-6), ${ }^{95-99}$ which stimulate the production of C-reactive protein (CRP) by the liver. The cardioprotective effects of adiponectin are attributed to its ability to suppress apoptosis, oxidative stress, and inflammation in cardiomyocytes. It may act directly on cardiomyocytes to protect the heart from ischemic injury, hypertrophy, cardiomyopathy, and systolic dysfunction. ${ }^{100-103}$ These results link adipose tissue-derived factors to overt CVD in humans; CRP, fibrinogen, and IL-6 are associated with CVD and death in general populations. ${ }^{95,104}$ Other factors, such as proinflammatory and prothrombotic states have also been associated with metabolic syndrome. ${ }^{75,105}$

\section{Nonspecific Biochemical Enzyme and Isoenzyme Markers of CVD}

The heart and vascular bed have typically been identified as the primary sites of atherosclerosis; the obesity epidemics 
have revealed that adipose tissue and liver play crucial roles in the development of risk factors for CVD.

Myocardium insult or injury is accompanied by elevated serum levels of the activities or mass of AST (EC 2.6.1.1), ${ }^{106}$ creatine kinase (EC 2.7.3.2), MB isoenzyme (CK-MB), ${ }^{107}$ and $\mathrm{LDH}$ (EC 1.1.1.27) isoenzyme $1^{108}$ because these enzymes are enriched in the myocardium compared with other tissues and in normal serum. ${ }^{109,110}$ This relationship is highly specific and sensitive for acute heart injury, notably acute MI (AMI). ${ }^{109,111}$ The World Health Organization recommends AST, CK, and LDH panel for the diagnosis of AMI. ${ }^{17}$ Elevated CK-MB levels, along with abnormal AST and LDH-1 was seen in some patient with chronic heart diseases, electric cardioversion for heart rhythm disturbances, coronary catheterization, and exercise.

Noncardiac pathological conditions also increase the activities of these enzymes. Skeletal muscle has low CK-MB levels, substantial injury increases CK-MB activities/mass in the blood, and reaches abnormal values. ${ }^{112}$ Another condition that can mimic MI in its clinical presentation is a pulmonary embolism (PE). ${ }^{113,114}$ AMI can be distinguished from PE by serial enzyme analysis of AST, CK-MB, and LDH-1 in serum out every $12 \mathrm{hr}$ for first $48 \mathrm{hr}$ by an accurately known time of onset of symptoms. The interorgan relationships and crosstalk between liver, muscle, kidney, and lung in the development of CVD have been studied extensively in adults.

\section{$A L T$ and $A S T$}

ALT and AST, also known as liver transaminases, are intracellular enzymes which catalysis transamination reaction between amino acids and ketonic acid. ${ }^{106}$ ALT is a widely used serum marker of the liver disease since it is predominantly found in hepatocytes. Unlike ALT, AST derived significant portions from other tissues such as heart, red blood corpuscles (RBC), and muscle; hence, it was the least desirable marker of liver function. Recent studies demonstrate the role of liver transaminases as independent predictors of cardiac-related morbidity and mortality. ${ }^{106,115-117}$

AST levels in the blood increase between 3 and $4 \mathrm{hr}$ after AMI, reach a peak level within 15-28 hr and return to normal range within 5 days. ${ }^{25}$ AST activity increased in several other clinical conditions such as hepatic congestion secondary to congestive HF, electrical cardioversion, myocarditis, and pericarditis. However, despite its high sensitivity for use in identifying AMI, AST is a nonspecific biomarker of cardiac tissue. ${ }^{118}$

Two distinct isoenzymes of AST exist in human tissues: cytosolic (soluble) AST (c-AST/s-AST) and mitochondrial AST (m-AST). These isoenzymes have different immunochemical and kinetic properties and amino acid composition. ${ }^{119}$ Compared with c-AST, m-AST is elevated after myocardial injury, ${ }^{120,121}$ increases later, and provides different biological information. ${ }^{122}$ Also, higher m-AST isoenzyme correlated significantly with the invasive hemodynamic estimation of LV dysfunction of myocardial necrosis in a subset of 15 AMI patients. ${ }^{121}$

ALT a commonly used prediction parameter of nonalcoholic fatty liver disease (NAFLD) and type 2 diabetes, and also few studies have been conducted to investigate the relationship between circulating ALT/AST and CHD. ${ }^{123,124}$ Furthermore, it has proposed that elevated circulating levels of ALT and AST are associated with endothelial dysfunction (carotid artery intima-media thickness and flow-mediated dilatation)-induced atherosclerosis and inflammation. ${ }^{125}$ Data from the Framingham Heart Study have shown, after adjusting for confounding variables, over a 10-year follow-up period among 3744 white adults in the United States who were free from clinical HF at baseline, there was an increased risk of $\mathrm{AF}$ associated with increased serum, either marker ALT or AST (>40 U/L). ${ }^{115,126}$ Thus, ALT and AST levels are independently associated with increased CVD-related mortality and serve as surrogate predictive markers in CVD progression. $106,116,117,124,127$

\section{Lactate dehydrogenase}

$\mathrm{LDH}$ is an omnipresent enzyme that transfers a hydride from one molecule to another, which catalyzes the interconversion of lactate to pyruvate, where it converts NAD+ to NADH and back again. It is a tetramer enzyme protein, and the two most common subunits are the LDH-M and LDH-H. These two subunits can form five possible tetramers (isoenzymes): $4 \mathrm{H}, 4 \mathrm{M}$, and the three mixed tetramers (3H1M, 2H2M, 1H3M). These tetramers are enzymatically alike; but isoforms show different tissue distribution: M4 has four muscle (M) subunits in the isoenzyme of skeletal muscle and liver, but $\mathrm{H} 4$ in most species, contains four heart (H) subunits, the principal isoenzyme for the heart muscle.

In AMI, the serum levels of LDH-1 are higher than LDH2 (a "flipped pattern") because damage to heart tissues releases the heart-specific isoenzyme into the circulation, which is rich in LDH-1, unlike normal condition LDH-2, which is the predominant circulating form. ${ }^{128,129}$ The ratio of LDH-1 to LDH-2 (LD1/LD2) is a well-known marker for the late diagnosis of $\mathrm{MI}^{130,131}$ because it provides more organ specificity than total $\mathrm{LDH}$ activity. ${ }^{32}$ The blood levels of both LDH and its isoenzyme LDH-1 are elevated 5-10 hr after AMI and reach maximum value within 60$144 \mathrm{hr}$, and return to normal range within 12 days. ${ }^{132} \mathrm{Di}-$ agnostic use of the LDH-1 isoenzyme is limited, however, because levels are typically elevated during acute renal failure and with hemolytic anemia. ${ }^{133}$ The use of LDH to diagnose MI is superseded by the measurement of cardiacspecific Troponin I or Troponin T. ${ }^{134}$

\section{Creatine kinase}

CK or creatine phosphokinase (CPK) also known as phosphocreatine ( $\mathrm{PCr}$ ) kinase, is a ubiquitous cytosolic enzyme. CK catalyzes the interconversion of creatine to $\mathrm{PCr}$ and with an expenditure of adenosine triphosphate (ATP) to adenosine diphosphate (ADP) and back again. ${ }^{135}$ This enzyme consists of two subunits, either B (brain type) or $\mathrm{M}$ (muscle type), which makes three different isoenzymes: CKMM, CK-BB, and CK-MB. Skeletal muscle expresses high levels of CK-MM (98\%) compared with CK-MB (1\%). In contrast, cardiomyocytes express CK-MM (70\%) and CKMB (25\%-30\%). Brain and smooth muscle, including vascular and uterine tissue, express CK-BB isoenzyme predominantly. In addition to these three cytosolic isoforms, the ubiquitous and the sarcomeric form of two mitochondrial CK isoenzymes are also present in tissues. ${ }^{136}$

Clinically, the blood CK assay is used as a marker of damage to $\mathrm{CK}$-rich tissue such as the damage that occurs in MI, ${ }^{135}$ acute kidney injury, autoimmune myositides, 
muscular dystrophy, and rhabdomyolysis (severe muscle breakdown). ${ }^{137} \mathrm{CK}-\mathrm{MB}$ levels increase with myocardial damage. ${ }^{135}$ The blood level of CK-MB, the bound combination of two variants (isoenzymes $\mathrm{CK}-\mathrm{M}$ and $\mathrm{CK}-\mathrm{B}$ ) of the enzyme PCr kinase, ${ }^{138}$ is a marker of AMI. It appears in the blood 3-9 hr after an AMI, a maximum value in the blood within $10-20 \mathrm{hr}$, and returns to normal range $\sim 72 \mathrm{hr}^{132}$; sensitivity is high if the blood is collected during the early onset of the disease. The primary source of CK-MB is the myocardium, although skeletal muscle is another source. The relative index is quantified by the ratio of CK-MB (mass; not activity) to total $\mathrm{CK}$ to distinguish false-positive elevations of CK-MB from skeletal muscle.

CK-MB1 and CK-MB2 are the isoenzymes of CK-MB. CK-MB2 is the tissue form released from the myocardium after an $\mathrm{MI}^{139}$ and rapidly converted peripherally into $\mathrm{CK}$ MB1 isoform after the onset of MI symptoms. Generally, CK-MB1 a major isoform; thus, the CK-MB2/CK-MB1 ratio is typically less than 1 . When CK-MB2 is elevated, and the ratio is $>1.7$, the result is positive. The recent improvement in measuring different isoforms of the B subunit specific to cardiomyocytes, the ratio between the CK-MB1 and CK-MB2 isoforms ${ }^{107}$ makes $\mathrm{CK}$ measurement a more specific and sensitive test for MI.

In the case of the children, the levels of CK-MB depend on the form of cardiomyopathies. In general, increased MB fraction is associated with the myocardial dysfunction with significantly higher levels with restrictive and dilated cardiomyopathy compared with a hypertrophic cardiomyopathy in children. ${ }^{140}$ Further studies of this aspect may provide validation for the use of CK-MB1 and CK-MB2 as early prognostic markers in predicting cardiac dysfunction in children with obesity or other risk factors.

\section{Myoglobin}

Myoglobin is a small globular oxygen-carrying protein found in the heart and striated skeletal muscle, with high homology sequence in both tissues. ${ }^{141,142}$ Levels of myo- globin rise rapidly after AMI, and it has become a valuable cardiac biomarker in the differential diagnosis of suspected $\mathrm{AMI}^{143}$ because plasma $\mathrm{CK}$ and CK-MB levels reach significant levels only $6 \mathrm{hr}$ after the necrosis. During MI, the levels of myoglobin rise during the $1-3 \mathrm{hr}$ of myocardial cell death after AMI, peak at $4-10 \mathrm{hr}$, and return to normal in 11.5 days $^{132,144,145}$ (Fig. 5).

The level of myoglobin is higher and cleared more rapidly from plasma after coronary reperfusion or no reperfusion (thrombolytic therapy) in patients and thus allows discrimination between these two conditions. ${ }^{146,147}$ Myoglobin levels in serum are falsely elevated under certain conditions, such as skeletal muscle and neuromuscular disorders, renal failure, intramuscular injection, and strenuous exercise, which was unrelated to AMI. ${ }^{148}$ Combining, skeletal-specific marker (carbonic anhydrase III) or a cardiac-specific marker (troponin I), as well as evaluation of successive myoglobin samples, may represent a novel strategy for myoglobin measurement that can resolve this.

\section{Glycogen phosphorylase isoenzyme BB}

Glycogen phosphorylase (GP) is an essential enzyme that regulates carbohydrate metabolism by mobilization of glycogen. It catalyzes first rate-limiting step of glycogenolysis, which converts glycogen into glucose-1-phosphate. ${ }^{149}$ GP exists in three different isoenzymes for the tissues in which they were initially identified, namely GPLL (liver), GPMM (muscle), and GPBB (brain). ${ }^{149,150}$ Higher levels of GPBB can also be found in the heart muscle, where the $94 \mathrm{kD}$ monomer is specifically present, which was comparable to other tissue concentrations. ${ }^{151}$

An early phase of AMI showed a rapid elevation of GPBB in the circulation. ${ }^{31,152}$ Hence, GPBB is ideal for early diagnosis of ischemic heart disease, with high sensitivity (0.97) and specificity (0.81) in patients with AMI within $3 \mathrm{hr}$ of the onset of symptoms. ${ }^{153} \mathrm{GPBB}$ is found in the heart and brain; a serum increase of GPBB should be considered highly specific for myocardial injury once

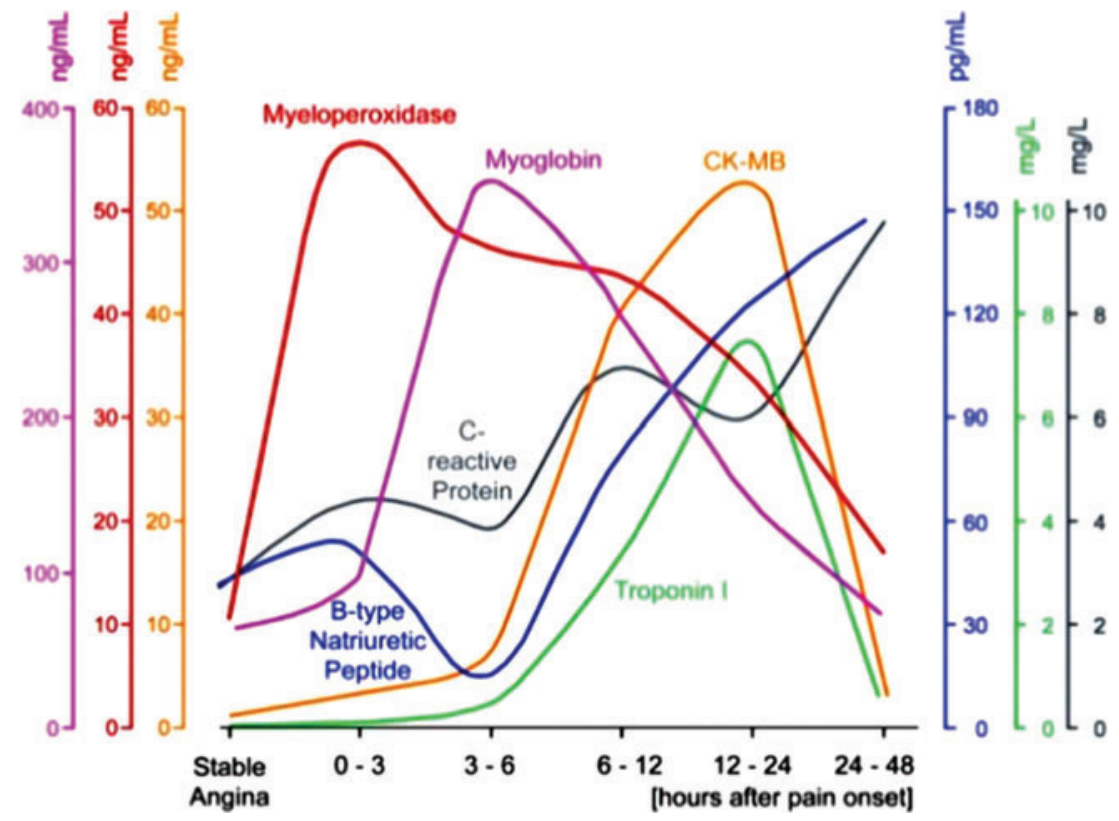

FIG. 5. Comparison of cardiac biomarkers after levels and time of peak after the onset of AMI. Source: https:// www.slideshare.net/anurag_yadav/cardiacbiomarker-past-today-and-future. AMI, acute myocardial infarction. Color images are available online. 
damage to the brain and resulting perturbation of the blood/brain barrier has been excluded. GPBB and glycogen are tightly associated with the vesicles of the sarcoplasmic reticulum in the aerobic heart muscle. During the onset of hypoxia that heralds ischemia, tissue glycogen is broken down, and GPBB is converted from a structurally bound form (GP b) into a free soluble cytoplasmatic form (GP a), thereby accelerating glycogen breakdown. ${ }^{151}$ A high concentration gradient of GP in the sarcoplasmic reticulum compartment allows efflux of GP into the bloodstream through the T-tubule system. ${ }^{151}$ Ischemia-induced structural alterations in the cell membrane ${ }^{151,154}$ effluxes GPBB into the extracellular fluid. Therefore, the amount of association with the sarcoplasmic reticulum glycogenolysis complex depends primarily on the metabolic state of the myocardium. ${ }^{155}$ Based on the localization of GPBB in the heart muscle and increased plasma levels of GP during ischemia and hypoxia, many studies have demonstrated that plasma GPBB is a surrogate marker of the ACS. ${ }^{151,155-158}$

\section{ST2}

ST2 is a member of an IL-1 receptor family and exists in transmembrane (ST2L) and soluble (sST2) isoforms. ${ }^{37,159,160}$ Cardiomyocytes secrete ST2L/sST2 into the circulation, whereas pulmonary endothelium does the same in response to inflammation and cardiac diseases. ${ }^{160-162}$ Secreted sST2 inhibits IL-33/ST2 signaling by functioning as a decoy IL-33 receptor, thus downregulating the inflammatory response. ${ }^{163}$ Patients with acute HF show higher levels of SST2 than in those without; N-terminal pro-brain type NP (NT-proBNP) is superior in the diagnosis of HF. ${ }^{161}$ High levels of SST2 correlate with the severity of disease and increased morbidity in patients with acutely decompensated HF and ACS. ${ }^{163}$

The ST2 transcripts upregulated in mechanically stimulated cardiomyocytes. Both ST2L and sST2 were induced by $\mathrm{HF}$, with the sST2 displaying a more robust expression. ${ }^{160}$ Also, data from the PRAISE-2 HF trial indicate that the independence of brain-type NP (BNP) and proatrial type NP (proANP), the alterations in ST2 remained significant as an interpreter of mortality or transplantation. ${ }^{37}$ Thus, serum sST2 may be a novel biomarker for neurohormonal activation in patients with $\mathrm{HF}^{37}$ Laterally, many studies have confirmed the prognostic value of $\mathrm{sST} 2$ in HF patients. ${ }^{161,164-166}$ compared with its minor value for diagnostic purposes. ${ }^{161,164,167}$ An advantage of sST2 compared with other NP markers is that its concentration is not affected by age, body mass index, or renal function. ${ }^{167}$ Hence, sST2 seems to be a specific potential marker for therapy guides for HF, but it is less sensitive than BNP for acute HF, which requires further evaluation. ${ }^{168,169}$

\section{Ischemia-modified albumin}

The conventional modern cardiac markers (CK-MB, Troponin I, and Troponin T) are more specific and represent a sensitive test for the detection of myocardial necrosis, but their levels are delayed, rising $\sim 3-6 \mathrm{hr}$ after the onset of the myocardial injury. Henceforth, it is one of the many reasons why it continues to be challenging to find diagnostic approaches for suspected clinical ACS or cardiac dysfunction. Early identification of patients with AMI is extremely critical. ${ }^{170}$ Because their presentations can vary widely with symptoms such as breathlessness, chest pain, epigastric discomfort, nausea, and vomiting may be subtle and not immediately associated with cardiac dysfunction ${ }^{170,171}$ and they are associated with high mortality. During acute myocardial ischemia, most of the biomarkers are negative, IMA is highly sensitive and detectable in the early reversible phase of ACS. ${ }^{171,172}$

IMA is a modified form of human serum albumin (HSA) in which the N-terminal amino acids have been modified by ischemia as the result of acidosis, energy-dependent membrane disruption, free-radical injury, and hypoxia. ${ }^{173}$ The increase in IMA levels occurs immediately after the onset of ischemia and returns to baseline values within $6-12 \mathrm{hr}$, thus enabling early identification of ischemia. ${ }^{174}$ Unlike other specific and sensitive markers, the levels of IMA surged early in the onset of disease, thus aiding in the diagnosis of acute ischemia before the onset of myocardial necrosis event. ${ }^{174}$

In 2003, the Food and Drug Administration (FDA) approved the albumin cobalt-binding (ACB) assay for the patients admitted to the emergency department in identifying myocardial ischemia. The binding of the cobalt enables the measurement of IMA to the damaged N-terminus of the albumin. ${ }^{175}$ The N-terminus of HSA is the primary binding site for the transitional metals, cobalt and copper. ${ }^{175,176}$ During ischemia, the metal-binding site in HSA is susceptible to biochemical changes compared with albumin from other species. The mechanism by which it reduces metalbinding ability at its N-terminal is unknown.

It has been assumed that IMA is "FA occupied" albumin rather than "N-terminal modified" albumin in patients with acute myocardial ischemia. However, instead of measuring IMA using an enzyme-linked immunosorbent assay (ELISA), it is better to use the standard ACB assay, which deals with "FA occupied" but not actually "N-terminal modified" albumin. ${ }^{34,176,177}$ Highly elevated serum levels of free fatty acids (FFA) with high levels of IMA correlated positively in myocardial ischemic patients. ${ }^{178}$ Thus, FFA binding alters conformational changes and inhibits the metal ion binding to albumin. ${ }^{179,180}$ Chronic diseases associated with "glycated/ oxidized" albumin, oxidative stress generates "irreversible" oxidation-modified albumin secondary to oxidation adducts on albumin. ${ }^{176}$ Henceforth, the use of both standard ACB assay and ELISA tests for determining IMA levels is ideal. Although the understanding of the IMA marker is limited, its sensitivity to and specificity for myocardial ischemia before cell damage may be an enormously valuable biomarker of prognosis. Further studies on the modification by modern proteomics tools would be interesting.

\section{Heart Tissue-Specific Novel Biomarkers}

The well-established traditional cardiovascular biomarkers (including LDL and HDL-C, glucose, and others) and many additional putative biomarkers (including MPO, pregnancy-associated plasma protein A, soluble CD40 ligand, and others) are not included in this review, because our focus is on the cardiac-specific biomarkers that show the most promise for use as clinical biomarkers.

\section{Cardiac troponins}

cTn are the machinery of the actin thin filaments of the sarcomere of striated muscle that regulates excitation/contraction 


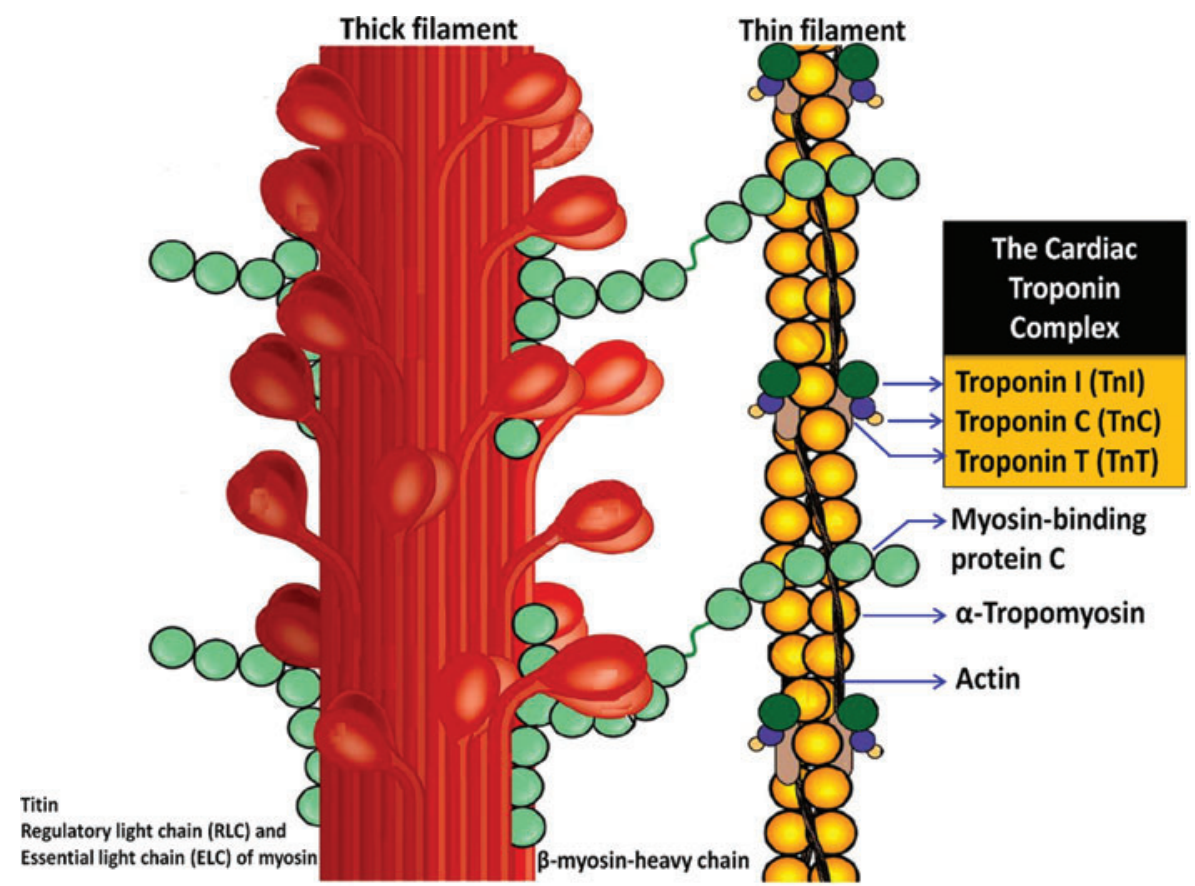

FIG. 6. The cTn complex. The troponin complex is a component of the thin filaments in striated muscle complexed to actin. There are three types of troponins: troponin $\mathrm{T}$ (tropomyosin binding), troponin I (inhibitory protein), and troponin $\mathrm{C}$ (calcium binding). The troponins are three different structurally unrelated proteins; cTnT and I differ significantly from the skeletal muscle form. cTnT, cardiac troponin T. Color images are available online. coupling in the heart (the contractile apparatus in the myocardium). ${ }^{181}$ Cardiac muscle-specific isoforms cTn subunits ( $\mathrm{T}=$ tropomyosin binding, $\mathrm{I}=$ inhibitory, and $\mathrm{C}=$ calcium binding), cardiac troponin $\mathrm{T}$ (cTnT), and cardiac troponin I (cTnI) expressed exclusively on the thin myofilament of the contractile apparatus, with a small proportion $(3 \%-6 \%)$ as unbound protein in the cytoplasm of myocytes (Fig. 6). ${ }^{182,183}$

Due to their high specificity and absolute cardiomyocyte specificity, cTnI and cTnT are now considered the ideal biomarkers for detecting cardiomyocyte injury, ${ }^{184,185}$ compared with cardiac enzymes or CK-MB mass. ${ }^{26}$

Circulating levels of cTn can be indicative of myocardial injury, and it is the preferred biomarker for the diagnosis of MI in all guideline-approved algorithms in the diagnosis of ACS. Troponin elevation following myocardial necrosis starts $\sim 2-3 \mathrm{hr}$ and peaks within $24 \mathrm{hr}$, and continue for $1-2$ weeks (Fig. 5). ${ }^{186}$ The detection of high-sensitivity cTnI is used to diagnose MI, and high-sensitivity assays for cTnT are used to predict the risk of CHD, HF, and death. ${ }^{187}$

Natriuretic peptides. NPs have attracted considerable attention as indicators of metabolic regulation in the cardiovascular system. ${ }^{188-191} \mathrm{NP}$ together is called as atrial NP (ANP) or factor. B-type NP (BNP), which was called initially brain NP, and C-type NP (CNP) with the ability to relax smooth muscle, was purified from porcine brain extracts. NP family members have highly conserved amino acid sequence homology with a typical characteristic ring structure. The heart expresses all types of NPs, but BNP and ANP are regarded as principally cardiac secretory products. ${ }^{192}$ In response to stretch, myocardium releases NP and promotes natriuresis, vasodilatation, and myocardial relaxation. ${ }^{193}$ All NPs are synthesized as preprohormones (Fig. 7A). NPs are reputable as markers of diagnosis and prognosis in $\mathrm{HF}$. However, due to prognosis indicators in a wide variety of disease states as well as in apparently healthy individuals, the usefulness of NP extends far beyond patients with acute or chronic HF. Also, NP plays a central role in the regulation of body weight and energy metabolic homeostasis. ${ }^{194}$
$N P$ receptors and their actions. The actions of NP are through membrane-bound receptors, NP receptor-A (NPR$\mathrm{A}$ ), which binds both ANP and BNP, and NP receptor-B (NPR-B), which binds CNP. Binding of the NP to their cognate receptors activates their guanylyl cyclase intracellular domain and produces cGMP, the second messenger that elucidates their downstream actions. NP receptor-C (NPR-C), a third receptor called the NP "clearance" receptor, because it lacks an intracellular domain, binds all three NPs (ANP, $\mathrm{BNP}$, and CNP) and internalizes the NP, which is then subjected to intracellular degradation. ${ }^{192,195}$ Possibly, NP is also degraded by peptidases in the circulation (Fig. 7B).

Atrial NP. ANP is a hormone synthesized by atrial cardiomyocytes and released in response to elevated atrial distention. Human pre-proANP is a 151 amino acid in length prohormone. N-terminal signal sequence cleavage resulted in a 126 amino acid proANP, which is the predominant stored form in atrial granules. Upon secretion, proANP is rapidly cleaved by a transmembrane cardiac serine protease called as Corin to form the biologically active C-terminal 28 amino acid peptide and the biologically inactive fragment (98 amino acid) N-terminal prohormone ANP (NTproANP) ${ }^{196}$ (Fig. 7A).

Atrial wall stretch or distension resulting from increased intravascular volume is the primary stimulus for ANP secretion. ${ }^{197}$ During HF, cardiac transmural pressure may promote ANP biosynthesis in the ventricles. Hypoxia or ischemia is one of the most potent stimuli for ANP secretion. ${ }^{198,199}$ Congestive HF elevates 10 - to 100 -folds of plasma levels of ANP (healthy patients are $\sim 20 \mathrm{pg} / \mathrm{mL}$ ). ${ }^{190}$ Both ANP and NT-proANP were used as markers for the diagnosis of asymptomatic LV dysfunction, ${ }^{200}$ and the severity of symptomatic HF was correlated with plasma ANP levels. Recently, however, measurement of BNP levels has been preferred due to its higher stability than ANP for diagnostic and prognostic use in HF. ${ }^{201}$

The proANP (126 amino acid), has a longer half-life and makes serum measurement more feasible; a novel assay that 


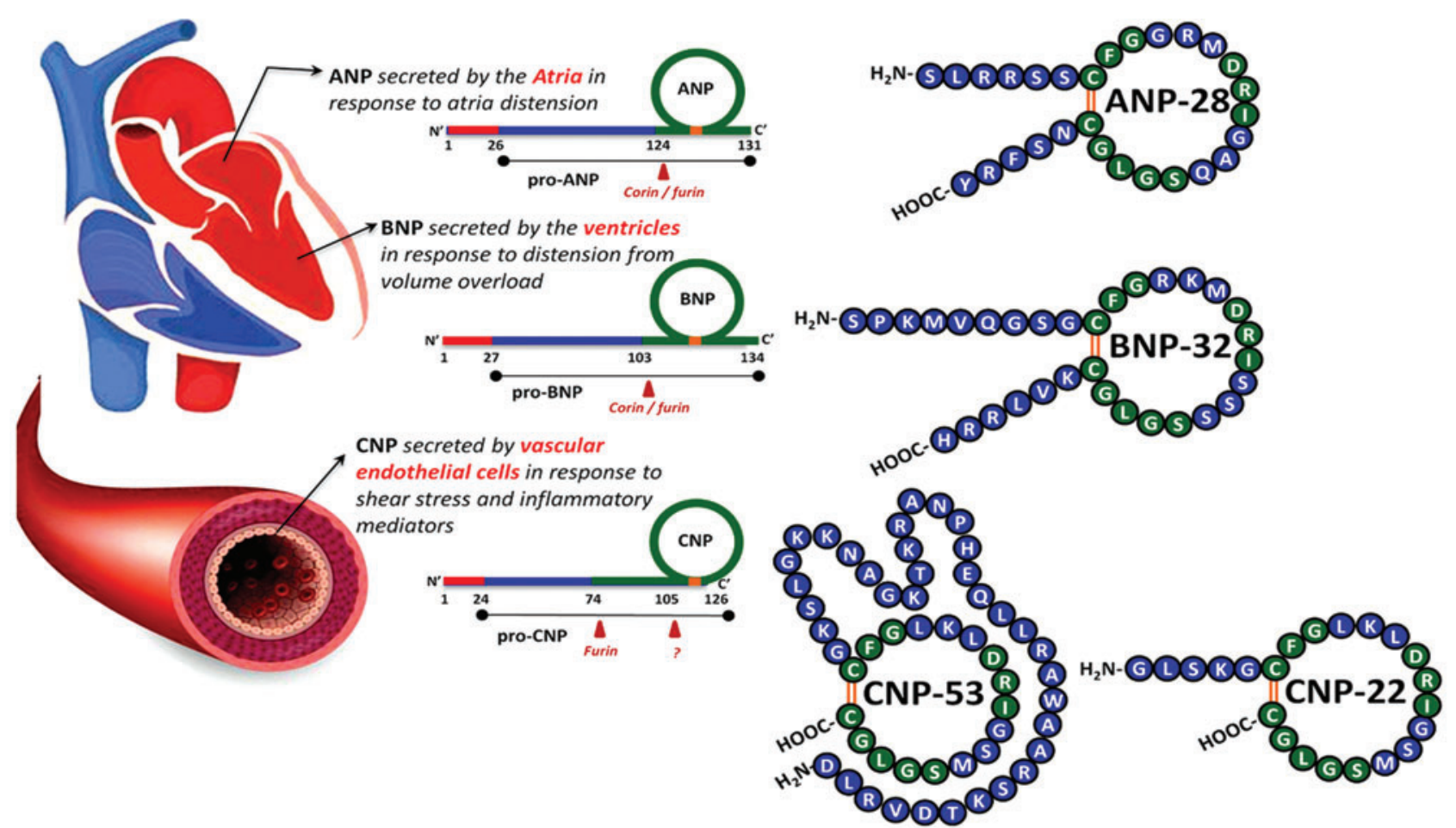

B Natriuritic peptide Receptors and its degradation

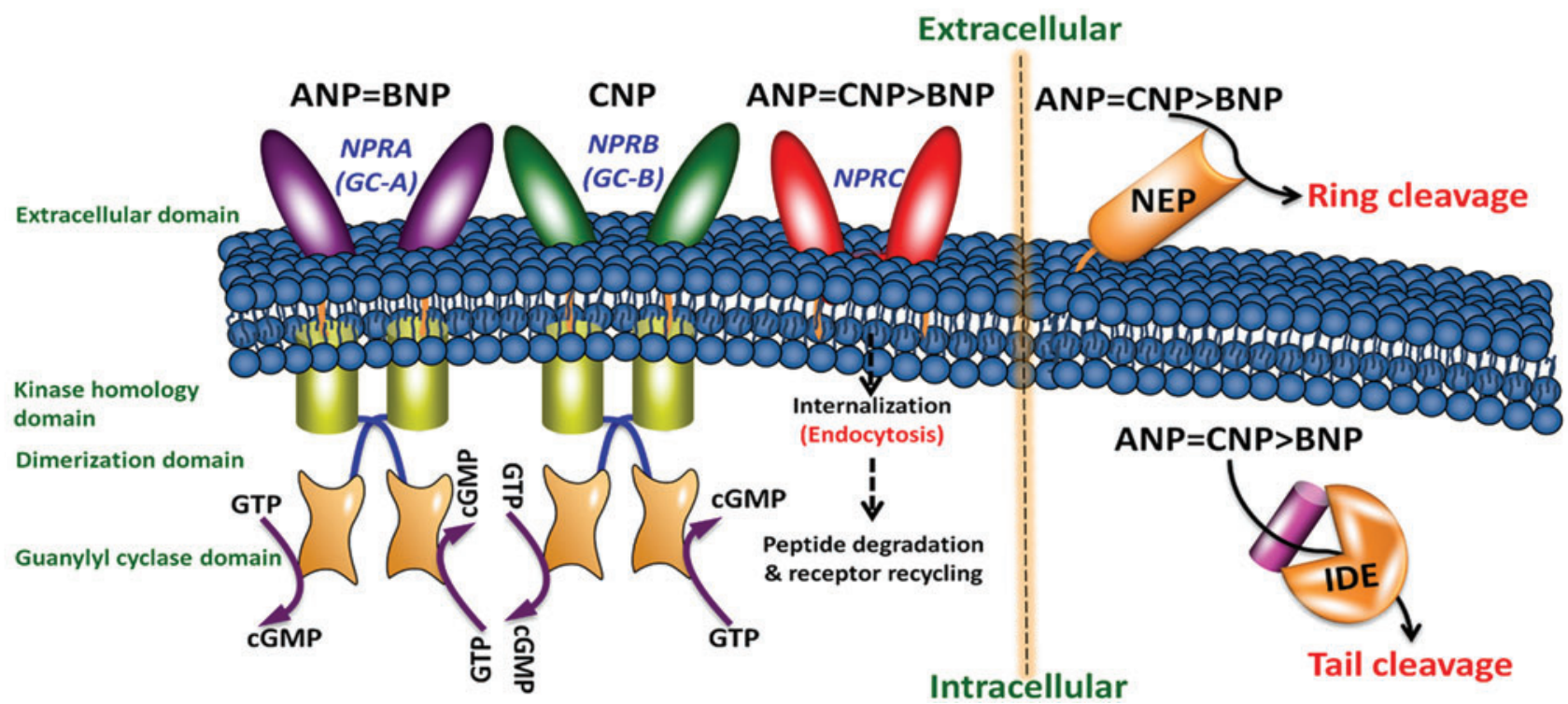

FIG. 7. Cardiac NPs system. (A) Tissue expression of NP, proteolytic processing of pre-pro-NPs to mature and biologically active peptides. (B) NP-binding receptors, intracellular signaling, and degradation processes. ANP, atrial natriuretic peptide; BNP, brain-type natriuretic peptide; cGMP, cyclic guanosine monophosphate; CNP, C-type natriuretic peptide; GC-A, guanylate cyclase type A; GC-B, guanylate cyclase type B; GTP, guanosine triphosphate; IDE, insulin-degrading enzyme; NEP, neprilysin; NP, natriuretic peptide; NPR, natriuretic peptide receptor. Color images are available online. 
detects the mid-regional zone of proANP (MR-proANP) is now available and has been evaluated as a test for $\mathrm{HF}^{202}$ In two studies, the Biomarkers in Acute HF (BACH, 1641 patients) trial ${ }^{203}$ and the PRIDE study ${ }^{204}$ show that measurements of MR-proANP improve the diagnostic accuracy of BNP gray zone (levels of BNP $\sim 100-500 \mathrm{pg} / \mathrm{mL}$ ) in obese patients. Hence, the combined use of MR-proANP and either BNP or NT-proBNP provides superior diagnostic precision compared with the use of either alone. ${ }^{205,206}$

B-type NP. Cardiomyocyte-specific BNP is synthesized as a preprohormone of 134 residues, containing a signal sequence that is cleaved to yield a 108 amino acid prohormone. The 108 amino acid precursor, proBNP, is produced in the cardiomyocytes, the biologically active C-terminal 32 amino acid BNP (BNP 1-32) and the inactive 76 amino acid Nterminal peptide [NT-proBNP] then processed by enzymes corin or furin by proteolytic cleavage between residues 76 and 77. Therefore, the heart secretes all three peptides; human BNP is 32 amino acids long but fully processed BNP length varies among species ${ }^{191,207}$; (Fig. 7A).

Currently, there are no specific data to support the use of any specific biomarkers as routine preclinical indices of CVD in obese children. BNP and cTn have gained importance as biomarkers in CVD. In adults, a relationship has been observed between plasma BNP/NT-proBNP or cTn levels in clinical CVD severity, particularly in HF. Also, it has been shown that NP plays a central role in the regulation of body weight and energy metabolism. ${ }^{194}$ Interestingly, the previous study shows that BNP levels are significantly lower in overweight and obese adult subjects than in those of healthy weight, ${ }^{208}$ probably contributing to insulin resistance and hypertension.

BNP inhibits renin and aldosterone secretion by decreasing sodium retention and increases the glomerular filtration rate. ${ }^{209}$ Healthy individuals have circulating plasma BNP concentrations of around $1 \mathrm{fmol} / \mathrm{mL}(3.5 \mathrm{pg} / \mathrm{mL})$. In case of patients with congestive HF, plasma BNP concentrations, as well as those of the inactive precursor NTproBNP, have been shown to increase up to 100 -fold. ${ }^{200}$ NT-proBNP concentrations in healthy individuals are $\sim 51 \mathrm{pg} / \mathrm{mL}$; the cutoff levels are $300 \mathrm{pg} / \mathrm{mL}$ for a diagnosis of acute $\mathrm{HF}$ and $125 \mathrm{pg} / \mathrm{mL}$ for chronic HF. For BNP, the cutoff concentrations for the diagnosis of acute and chronic $\mathrm{HF}$ are 100 and $35 \mathrm{pg} / \mathrm{mL}$, respectively. ${ }^{210}$ The normal ranges and cutoff points of the two markers are different because concentrations of NT-proBNP are substantially higher than those of BNP due to a longer half-life. Tests for both of these peptides are commonly used as markers of prognosis in chronic HF condition and to rule out the diagnosis of HF. Both BNP and NT-proBNP are established markers of HF; however, their measurements are not interchangeable. The BNP/NT-proBNP is also used as a biomarker of HF in children. Even though there is a steep age-dependent variation in healthy individuals, concentrations are $\sim 3000 \mathrm{pg} / \mathrm{mL}$ in infants $0-2$ days of age compared with concentrations of $\sim 100 \mathrm{pg} / \mathrm{mL}$ for children between 1 month and 1 year of age. ${ }^{211-213}$

NT-proBNP is unable to activate NPR-A and generate cGMP, and the ability of proBNP to do so is markedly reduced. This reduced activation of NPR-A by proBNP and NT-proBNP is highly relevant to the pathophysiology of HF as increasing evidence demonstrates that proBNP and not BNP 1-32 is the predominant circulating form. ${ }^{214}$ BNP 1-32 undergoes further processing by dipeptidyl peptidase IV, which removes the two N-terminal amino acids (Ser and Pro), producing BNP 3-32. ${ }^{215}$ Importantly, BNP 3-32 is also in the circulation, and its concentrations increase in human $\mathrm{HF}^{216}$ Its physiological significance is high since BNP 3-32 as compared with BNP 1-32 has reduced natriuretic and diuretic properties and lacks renal vasodilatation. ${ }^{217}$

Sensitive MS methods have identified many new circulating forms of truncated, low molecular mass proBNP, and NT-proBNP. The proBNP (3-108) peptide circulates at relatively low concentrations in healthy subjects, but in patients with asymptomatic LV dysfunction or HF concentrations of proBNP are elevated several folds. Circulating forms of proBNP are produced by the action of either circulating or cell surface enzymes, such as neprilysin, dipeptidyl peptidase IV, insulin-degrading enzyme, and meprin (Fig. 7B). ${ }^{192}$ Thus, chronic HF represents a state of relative $\mathrm{BNP}$ deficiency.

HF may represent a deficient state of biologically active NP. The abnormality in the processing of NP, leading to a deficiency of mature BNP conversely elevated levels of biologically inactive BNP detected in chronic HF. ${ }^{218}$ Also, myocardial NEP mRNA levels elevated in the patients with $\mathrm{HF}$, leading to accelerated degradation of NP, supports the hypothesis that a deficiency of NP may be present in $\mathrm{HF}^{219}$ and may be due to abnormal processing or accelerated degradation. At the same time, the glycosylation and truncation of these peptides offer considerable scope for new BNP form-specific assays that may better reflect the presence, progression, or prediction of HF and its outcome.

C-type NP. CNP complements the endocrine actions of ANP and BNP by serving as a paracrine component of the $\mathrm{NP}$ axis. CNP is the widely expressed NP in the brain and chondrocytes, and cytokine-exposed endothelial cells secrete highest concentrations. ${ }^{220-222}$ In humans, the primary source of circulating CNP are endothelial cells and heart. ${ }^{222}$ Hence, it appears to play a significant role in vascular and cardiac function, both physiologically and pathologically. Both the endogenous and exogenous CNP may offer protection from ischemia/reperfusion injury. Mice overexpressing CNP in cardiomyocytes show reduced pathologies such as ventricular hypertrophy, necrosis, inflammation, and functional impairment of cardiac tissue induced by coronary artery ligation ${ }^{223,224}$ (Fig. 7A).

Human proCNP 103 residues are processed to produce the mature 53 amino acid peptide by an intracellular endoprotease, Furin, ${ }^{225}$ which is the predominant form in the brain, ${ }^{226}$ endothelial cells, ${ }^{227}$ and heart. ${ }^{228}$ CNP-22 is the cleaved peptide from CNP-53 by an unknown extracellular enzyme; both elicit similar, if not, identical functions, ${ }^{229}$ but their tissue expression differs (Fig. 7A). CNP does not behave as an exclusive cardiac-specific hormone, although its potential role in HF cannot be ruled out. ${ }^{191}$ Elevated in patients plasma CNP concentrations (CNP-53/22 form) with congestive HF compared with the healthy subjects are in the low $\mathrm{fmol} / \mathrm{mL}$ range. ${ }^{230}$

\section{Cardiac myosin light chain kinase}

The cardiac myosin light chain kinase (cMLCK) is expressed only in the heart, in both the atria and ventricles. ${ }^{21,23}$ cMLCK plays an essential role in maintaining the phosphorylation levels of regulatory MLC2, a cardiac isoform of 
the regulatory light chain thought to be crucial for the regulation of cardiac function. cMLCK was identified in the heart $^{21,231}$ and has been reported to be an essential kinase for MLC2 phosphorylation. $^{21,231,232}$ In the myocardium, cMLCK is responsible for the basal phosphorylation of both MLC2 $v$ and MLC2a in vivo ${ }^{233}$ and alters structural changes in both thick and thin filaments that enhance contraction of heart muscle. ${ }^{234}$ The contractile dysfunction, ventricular hypertrophy, necrosis, and fibrosis was seen in the selective abolishment of MLC $2 \mathrm{v}$ phosphorylation. ${ }^{211,233,235,236}$ cMLCK was identified in human $\mathrm{HF}^{21}$ where it may play an essential role in adaptive responses to pathophysiological stresses in the heart. $^{21,233,235-237}$

A reduction in phosphorylation of MLC2 was demonstrated in adult patients with $\mathrm{HF}^{238-240}$ Mylk3 gene that encodes cMLCK was ablated either from the germline or inducibly in adulthood; both populations of cMLCKdeficient mice exhibited $\mathrm{HF}^{237,241}$ To the best of our knowledge, it remains unknown whether phosphorylation of MLC2 or its active kinase, cMLCK, is reduced in children with HF.

\section{Heart-type fatty acid-binding protein}

FABP are a family of cytoplasmic or intracellular fatty acid transporters. $^{242}$ There are brain-type FABP (B-FABP), intestinal-type FABP (I-FABP), liver-type FABP (L-FABP), and H-FABP ${ }^{242,243}$ evolved by successive gene duplications generating a large number of tissue-specific homologs. Higher rates of FA uptake and lipid metabolism tissues have high expression of one or more FABPs. This vast diversity of FABPs, which contrasts sharply with other lipid-binding proteins, has long been suggestive of functional specialization. ${ }^{242}$

Since H-FABP exists mainly in cardiomyocytes, it becomes a potentially promising biomarker for myocardial injury. ${ }^{36,244}$ FABP family members involved in active fatty acid metabolism, functionally H-FABP also do the same, where it transports FAs from the cell membrane to mitochondria for oxidation. ${ }^{245}$ This FABP are believed to participate in the uptake, intracellular metabolism, and transport of long-chain polyunsaturated fatty acids. H-FABP is rapidly released into the cytosol early in AMI. ${ }^{245}$

$\mathrm{H}-\mathrm{FABP}$ represents $60 \%$, which is significantly higher and superior sensitivity than that of cTnI (18.8\%) and CKMB (12.5\%) and adds incremental value to troponin in early diagnosis of an ACS (within $5 \mathrm{hr}$ of the onset of symptoms). ${ }^{36,246-250}$ However, the specificity was only $23.53 \%$, which is less than that of CK-MB (100\%) and cTnI $(66.67 \%)$. During the period from 4 to $12 \mathrm{hr}$ of the onset of symptoms, the sensitivity of H-FABP was $86.96 \%$, which was comparable to $\mathrm{cTnI}$ and $\mathrm{CK}-\mathrm{MB}$ without compromising specificity. $^{36,246-250}$

The mechanism of H-FABP leakage in a failing heart has been elucidated in a few animal studies. Insulin-like growth factor 1 signaling inhibits microRNA-1 expression and plays a critical role in cardiac hypertrophy, which results in a release of H-FABP from myocardial tissues to circulation. ${ }^{251}$ During HF, the energy substrate used switches from reduced FA oxidation to increased glucose utilization, which differs from the cardiac metabolic process in a healthy heart. $^{252-255}$ It was shown that in H-FABP knockout mice there was depressed cellular uptake of long-chain FA and its oxidation, indicating the critical role of $\mathrm{H}$-FABP cardio- myocytes. $^{255}$ Furthermore, extracellular circulating AFABP and H-FABP suppress cardiomyocyte contraction by reduced excitation/contraction coupling through reduced intracellular transient calcium. ${ }^{256}$ In obese subjects, adipocytes FABP4 may be involved in the initiation or progression of cardiac contractile dysfunction. Through the alteration of cardiac energy metabolism and cardiac dysfunction, H-FABP leakage from damaged myocardium in the failing heart may contribute to a vicious cycle that finally leads to poor clinical outcomes.

Additionally, an H-FABP level increased in association with more significant number of cardiovascular risk factors and was an independent risk factor for all causes of cardiovascular death. It is noteworthy that circulating H-FABP concentrations are elevated in NAFLD and metabolic syndrome as well as in obesity, ${ }^{257-261}$ signifying that H-FABP is one of the markers of insulin resistance and subclinical myocardial damage that exist in these patients. For this reason, the diagnostic accuracy of $\mathrm{H}-\mathrm{FABP}$ may make it a useful indicator for the early prediction of high-risk patients in the general population, ${ }^{244,262}$ as well as being considered a useful marker for assessing ongoing myocardial damage.

\section{Noninvasive Anatomical and Electrophysiological Cardiac Biomarkers}

The commonly used CVD surrogate biomarkers include (1) Soluble biomarkers (lipids and inflammatory markers), acute-phase proteins, and adipokines; (2) Physiological measures (blood pressure, endothelial function, and vascular stiffness); and (3) Anatomical measures [CIMT and CAC]. The measurement of CVD biomarkers at multiple points along the pathophysiological pathway as indicators of disease traits, disease state, the rate of progression, or as surrogate endpoints for treatment trials are useful. ${ }^{16}$ Also, a growing body of research suggests that noninvasive measures of vascular morphology and functions may predict pediatric cardiometabolic risk factors' early presence of surrogate markers must predict later onset of CVD. ${ }^{263,264}$ Also, the limitations of surrogate markers such as involved in the multipathway process, are not involved in diseases and inappropriately sensitive or responsive to intervention, and often lack methodological standardization in children. ${ }^{264}$

\section{Carotid intima-media thickness}

The risk of future CVD events, including MI and death correlates with CIMT ultrasound measurements. ${ }^{265-267} \mathrm{Ab}$ solute quantitative measurements of the CIMT and its change over time is assessed by advanced B-mode ultrasound imaging techniques. ${ }^{268}$ CIMT measurement is an adequate alternative assessment for atherosclerosis (arterial system) and CV events (a surrogate endpoint) in intervention studies. ${ }^{263,268,269}$ The rich dataset includes 23.4 years of longitudinal follow-up on 2893 twelve- to 18-year-old participants from four studies from the International Childhood Cardiovascular Cohort (i3C). Data collected across three continents show that childhood obesity, hypertension, and dyslipidemia in adolescence predict the presence of high CIMT in adulthood. ${ }^{73}$ Thus, the clinical cardiovascular endpoints of atherosclerosis can be assessed by standard CIMT measurement in younger populations. ${ }^{69}$ 


\section{Coronary artery calcification}

Patients with a high prevalence of CHD show CAC and are associated with significant adverse cardiovascular events. ${ }^{270-272}$ There are two common types of CAC, intimal and medial calcification, each of which has specific risk factors. Medial calcification is associated with arterial stiffness, which increases the risk of adverse cardiovascular events. ${ }^{271}$ The foremost noninvasive tool used to detect calcified lesions is coronary CT angiography. ${ }^{270}$ Since adiposity is the primary determining factor of CAC in obese youth and adults, CAC is the independent risk factor used to predict subclinical atherosclerosis. 273,274

\section{Dysfunction of the autonomic nervous system and HRV}

The autonomic nervous system (ANS) has an essential influence on the progression of CVD. The two halves of the ANS, the parasympathetic nervous system (PNS) and the SNS, cooperate to control heart rate, cardiac output, myocardial contractility, and constriction and dilatation of blood vessels. ${ }^{275,276}$ Dysfunction of the ANS contributes to the development or stabilization of obesity and is associated with cardiovascular mortality. ${ }^{277}$ The study of ANS function in obesity is of considerable clinical interest. Methods used to assess ANS function outside the cardiac system include sympathetic skin response and quantitative pupillography. ${ }^{278}$ The cardiac autonomic modulation of HRV analysis has a direct association with cardiovascular prognosis. ${ }^{279}$ The lower the HRV, the higher the chance that coronary events will occur. ${ }^{280}$ Additionally, the dysfunction of autonomic cardiac control has been described among the pathophysiologic characteristics of childhood obesity. ${ }^{281-283}$ Among obese children and adolescents, reductions in HRV and vagal modulation have been observed during the increase of the sympathovagal balance. ${ }^{281,282,284}$

Cardiac autonomic dysfunction is a risk factor for the development of CVD that can be measured noninvasively using HRV. ${ }^{285}$ HRV is thought to be the result of an adaptive response in heart rate caused by the SNS and PNS working together to buffer blood pressure. ${ }^{286}$ Altered compensatory change (low HRV) suggests a decreased adaptive ANS and is associated with increased morbidity. HRV is associated with morbidity and mortality after MI. ${ }^{287-289}$ AMI, cardiac death, congestive HF, and arrhythmias have also been associated with reduced HRV. ${ }^{290-293}$
Two different methods of electrocardiogram (ECG) are employed to assess the cardiac autonomic nerve functions, temporary differences between continuous ventricular depolarization consist of three waves QRS complexes ( $R-R$ intervals) and the spectral analysis of the ECG. ${ }^{294}$ This has been validated and has demonstrated good reproducibility, high sensitivity, and specificity is the analysis of time-domain measures of HRV. ${ }^{295}$ For accurate determination of HRV, standardized conditions are necessary, since it can be influenced by many factors, including age, heart and respiratory rate, blood pressure, food ingestion, coffee consumption, smoking, body position, volume status, mental stress, drugs, exercise, and time of day. ${ }^{296}$ However, the majority of studies that assessed HRV in obese children and adolescents showed significantly higher blood pressures than their nonobese peers. ${ }^{281,283}$ There is a direct association between high arterial blood pressure and the impairment of cardiac autonomic modulation. ${ }^{297,298}$ Hence, this change in the hemodynamic characteristic may itself be an independent cause of the cardiac autonomic dysfunction observed in this population.

\section{MicroRNAs and Exosomal miRNAs Are Gene Regulators and Emerging Biomarkers with Therapeutic Potential}

MicroRNAs are involved in the developmental processes in vertebrates. Apart from that, the role of specific miRNAs in certain disease conditions may provide insight into disease pathogenesis and potential mechanisms of repair. ${ }^{299,300}$ Exchange of information between organs may occur through exosomes; since it has been identified in body fluids and blood, they are made exosomes and their specific cargo potential biomarkers. ${ }^{301}$ Exosomal miRNAs may reflect disease-specific aberrations. Additionally, exosomes may deliver the contents (proteins, mRNAs, miRNAs, and DNAs) to target specific cells that contain cell-specific factors that allow the exosomes to deliver the exosomal contents to recipient cells with a high degree of efficiency. Research on CVD with some exosome cargos (miRNAs, lipids, and proteins) provide the development of noninvasive discovery of novel biomarkers. ${ }^{299,300,302,303}$ However, their clinical use remains juvenile. A study, utilizing genetically modified mice, shows the critical requirement for miRNAs in cardiac development, as mice deficient in Dicer experience cardiac failure. ${ }^{304}$ In patients with CVDs, the circulating exosome-derived miR-133a levels are elevated from injured myocardium. ${ }^{305}$ miR-133a is implicated in the

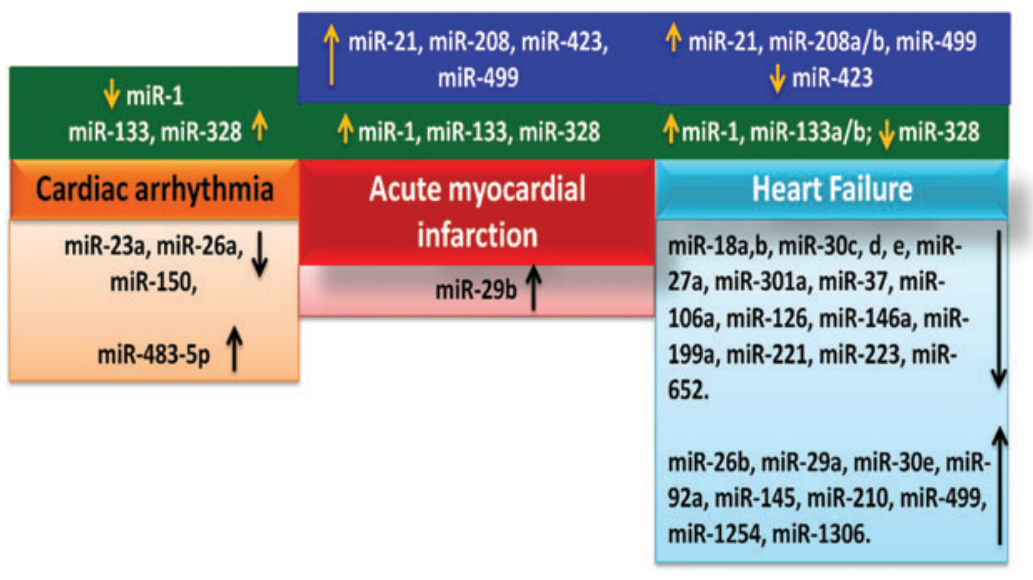

FIG. 8. Diagnosis and prognosis miRNAs biomarkers associated with cardiac arrhythmia, AMI, and HF. miRNAs in drop-down boxes are associated with a single respective pathology, while those in blue and green boxes represent multiple corresponding pathologies. Ý; increased and, $B$; decreased in the specific pathology conditions. HF, heart failure. Color images are available online. 
regulation of NFATc4, a protein that contributes to cardiac hypertrophy. ${ }^{306}$ Furthermore, treatment of miR-133a inhibitors reduces the level of cardiac hypertrophy. ${ }^{306}$

The levels of miR-22, 99a, 214, and 21 increased expression or decreased expression of miR-15, 320, 132, 212, 652, 92a, and 34 , which provides beneficial or protective effects in the treatment of $\mathrm{CVD}^{299,302,303}$ (Fig. 8). miRNAs regulate numerous biological processes, and many human diseases influence their levels of expression. Numerous challenges need to be addressed to identify miRNAs that can be reliably used as diagnostic markers or therapeutic targets for CVD and the critical role of miRNA in cardiovascular biological function.

\section{Current Challenges and Clinical Perspective of Cardiac Biomarkers}

Noninvasive measurement of end-organ function has advanced considerably with the development of cardiovascular imaging techniques, and the detection of preclinical CVD in children and youth has become more feasible. ${ }^{263}$ Depending on the marker, it can take between 2 and $24 \mathrm{hr}$ for the level to increase in the blood. Additionally, determining the levels of cardiac markers in the laboratory-like many other laboratory measurements-takes substantial time. Cardiac markers are therefore not useful in diagnosing MI in the acute phase. The clinical presentation and results from an ECG are more appropriate in the acute situation. Nevertheless, long-term studies in children assessing the relationship between preclinical CVD and novel biomarkers/risk factors and its biology of the action with multiplexed detection panel are only emerging.

\section{Conclusion}

Childhood obesity has reached epidemic proportions worldwide. Several epidemiological studies identified childhood obesity and CVD risk markers in childhood as risk factors for CVD in adulthood. ${ }^{307-310}$ These risk factors underlie future microvascular and macrovascular disease events. Taken together, the occurrence and development of CVD are related and caused by multiple factors. Classic risk factors of CVD include type 2 diabetes, hypertension, dyslipidemia, history of smoking, and family history of CVD. Management of risk factors achieved by lifestyle changes such as sensible diet, exercise, controlling the intake of cholesterol and fat, intake of more fruits and vegetables, smoking cessation, drinking cessation, and reduction in passive smoking are exceedingly helpful in preventing CVD.

The U.S. National Institutes of Health/FDA in 2001 defined a biomarker as a characteristic that is objectively measured and evaluated as an indicator of normal biological processes, pathogenic processes, or pharmacological responses to a therapeutic intervention. ${ }^{311}$ The levels of an ideal biomarker should be measurable in a sample such as blood, urine, or tissue biopsy and should relate to a clinical phenotype either causally or indirectly to measure the status of the diseases. The understanding of invasive and noninvasive cardiac-specific biomarkers and the risk factors may yield valuable insights into the pathophysiology and prevention of CVD in a high-risk obese population at an early stage.

\section{Acknowledgments}

The authors thank Mr. William McLean and Mr. Christopher M. Stevens for excellent editing assistance.

\section{Author Disclosure Statement}

No conflicting financial interests exist.

\section{Funding Information}

The authors are supported by grants from the Malcolm W. Feist Cardiovascular Research Fellowship to R.P. and Malcolm Feist Endowed Chair in Diabetes to S.K.J. from the Center for Cardiovascular Diseases and Sciences (CCDS), Louisiana State University Health Sciences Center, Shreveport.

\section{References}

1. De Marchi E, Baldassari F, Bononi A, et al. Oxidative stress in cardiovascular diseases and obesity: Role of p66Shc and protein kinase C. Oxid Med Cell Longev 2013;2013:564961.

2. Niemann B, Rohrbach S, Miller MR, et al. Oxidative stress and cardiovascular risk: Obesity, diabetes, smoking, and pollution: Part 3 of a 3-part series. J Am Coll Cardiol 2017;70:230-251.

3. Yusuf S, Reddy S, Ounpuu S, et al. Global burden of cardiovascular diseases: Part I: general considerations, the epidemiologic transition, risk factors, and impact of urbanization. Circulation 2001;104:2746-2753.

4. Doupa D, Seck SM, Dia CA, et al. Dyslipidemia, obesity and other cardiovascular risk factors in the adult population in Senegal. Pan Afr Med J 2014;19:181.

5. Moran AE, Roth GA, Narula J, et al. 1990-2010 global cardiovascular disease atlas. Glob Heart 2014;9:3-16.

6. Ofori-Asenso R, Garcia D. Cardiovascular diseases in Ghana within the context of globalization. Cardiovasc Diagn Ther 2016;6:67-77.

7. McGill HC, Jr., McMahan CA, Gidding SS. Preventing heart disease in the 21st century: Implications of the Pathobiological Determinants of Atherosclerosis in Youth (PDAY) study. Circulation 2008;117:1216-1227.

8. Highlander P, Shaw GP. Current pharmacotherapeutic concepts for the treatment of cardiovascular disease in diabetics. Ther Adv Cardiovasc Dis 2010;4:43-54.

9. Kvan E, Pettersen KI, Sandvik L, et al. High mortality in diabetic patients with acute myocardial infarction: Cardiovascular co-morbidities contribute most to the high risk. Int J Cardiol 2007;121:184-188.

10. Norhammar A, Malmberg K, Diderholm E, et al. Diabetes mellitus: The major risk factor in unstable coronary artery disease even after consideration of the extent of coronary artery disease and benefits of revascularization. J Am Coll Cardiol 2004;43:585-591.

11. Glucose tolerance and mortality: Comparison of WHO and American Diabetes Association Diagnostic Criteria. The DECODE study group. European Diabetes Epidemiology Group. Diabetes Epidemiology: Collaborative analysis of Diagnostic criteria in Europe. Lancet 1999;354:617-621.

12. Vergeer M, Holleboom AG, Kastelein JJ, et al. The HDL hypothesis: Does high-density lipoprotein protect from atherosclerosis? J Lipid Res 2010;51:2058-2073.

13. Mihl C, Loeffen D, Versteylen MO, et al. Automated quantification of epicardial adipose tissue (EAT) in coronary CT angiography; comparison with manual assessment and correlation with coronary artery disease. J Cardiovasc Comput Tomogr 2014;8:215-221.

14. Chan CP, Rainer TH. Pathophysiological roles and clinical importance of biomarkers in acute coronary syndrome. Adv Clin Chem 2013;59:23-63. 
15. Tzoulaki I, Siontis KC, Evangelou E, et al. Bias in associations of emerging biomarkers with cardiovascular disease. JAMA Intern Med 2013;173:664-671.

16. Vasan RS. Biomarkers of cardiovascular disease: Molecular basis and practical considerations. Circulation 2006; 113:2335-2362.

17. Nomenclature and criteria for diagnosis of ischemic heart disease. Report of the Joint International Society and Federation of Cardiology/World Health Organization task force on standardization of clinical nomenclature. Circulation 1979;59:607-609.

18. Bodor GS, Porter S, Landt Y, et al. Development of monoclonal antibodies for an assay of cardiac troponin-I and preliminary results in suspected cases of myocardial infarction. Clin Chem 1992;38:2203-2214.

19. Burnett JC, Jr., Kao PC, Hu DC, et al. Atrial natriuretic peptide elevation in congestive heart failure in the human. Science 1986;231:1145-1147.

20. Cantin M, Genest J. The heart and the atrial natriuretic factor. Endocr Rev 1985;6:107-127.

21. Chan JY, Takeda M, Briggs LE, et al. Identification of cardiac-specific myosin light chain kinase. Circ Res 2008; 102:571-580.

22. Dreyfus JC, Schapira G, Demos J. [Study of serum creatine kinase in myopathic patients and their families]. Rev Fr Etud Clin Biol 1960;5:384-386.

23. Ishikawa Y, Kurotani R. Cardiac myosin light chain kinase: A new player in the regulation of myosin light chain in the heart. Circ Res 2008;102:516-518.

24. Jougasaki M, Wei CM, McKinley LJ, et al. Elevation of circulating and ventricular adrenomedullin in human congestive heart failure. Circulation 1995;92:286-289.

25. Karmen A, Wroblewski F, Ladue JS. Transaminase activity in human blood. J Clin Invest 1955;34:126-131.

26. Katus HA, Remppis A, Looser S, et al. Enzyme linked immuno assay of cardiac troponin $\mathrm{T}$ for the detection of acute myocardial infarction in patients. J Mol Cell Cardiol 1989;21:1349-1353.

27. Katus HA, Yasuda T, Gold HK, et al. Diagnosis of acute myocardial infarction by detection of circulating cardiac myosin light chains. Am J Cardiol 1984;54:964-970.

28. Larue C, Defacque-Lacquement H, Calzolari C, et al. New monoclonal antibodies as probes for human cardiac troponin I: Epitopic analysis with synthetic peptides. Mol Immunol 1992;29:271-278.

29. Lees MH. Catecholamine metabolite excretion of infants with heart failure. J Pediatr 1966;69:259-265.

30. Panteghini M. Diagnostic application of CK-MB mass determination. Clin Chim Acta 1998;272:23-31.

31. Rabitzsch G, Schulz H, Onnen K, et al. Immunoinhibition assay of the serum activity of human glycogen isophosphorylase $\mathrm{BB}$ in the diagnosis of the acute myocardial ischaemia. Biomed Biochim Acta 1987;46:S584-S588.

32. Rosalki SB. An improved procedure for serum creatine phosphokinase determination. J Lab Clin Med 1967;69: 696-705.

33. Rosalki SB, Wilkinson JH. Reduction of alphaketobutyrate by human serum. Nature 1960;188:11101111.

34. Sinha MK, Gaze DC, Tippins JR, et al. Ischemia modified albumin is a sensitive marker of myocardial ischemia after percutaneous coronary intervention. Circulation 2003; 107:2403-2405.

35. Stone MJ, Willerson JT, Gomez-Sanchez CE, et al. Radioimmunoassay of myoglobin in human serum. Re- sults in patients with acute myocardial infarction. $J$ Clin Invest 1975;56:1334-1339.

36. Vupputuri A, Sekhar S, Krishnan S, et al. Heart-type fatty acid-binding protein (H-FABP) as an early diagnostic biomarker in patients with acute chest pain. Indian Heart J 2015;67:538-542.

37. Weinberg EO, Shimpo M, Hurwitz S, et al. Identification of serum soluble ST2 receptor as a novel heart failure biomarker. Circulation 2003;107:721-726.

38. Wroblewski F, Ladue JS. Lactic dehydrogenase activity in blood. Proc Soc Exp Biol Med 1955;90:210-213.

39. Gordon-Larsen P, The NS, Adair LS. Longitudinal trends in obesity in the United States from adolescence to the third decade of life. Obesity (Silver Spring) 2010;18: 1801-1804.

40. Jensen MD, Ryan DH, Apovian CM, et al. 2013 AHA/ACC/TOS guideline for the management of overweight and obesity in adults: A report of the American College of Cardiology/American Heart Association Task Force on Practice Guidelines and The Obesity Society. J Am Coll Cardiol 2014;63(25 Pt B):2985-3023.

41. May AL, Kuklina EV, Yoon PW. Prevalence of cardiovascular disease risk factors among US adolescents, 1999-2008. Pediatrics 2012;129:1035-1041.

42. Bass R, Eneli I. Severe childhood obesity: An underrecognised and growing health problem. Postgrad Med J 2015;91:639-645.

43. Lloyd LJ, Langley-Evans SC, McMullen S. Childhood obesity and risk of the adult metabolic syndrome: A systematic review. Int J Obes (Lond) 2012;36:1-11.

44. Singh AS, Mulder C, Twisk JW, et al. Tracking of childhood overweight into adulthood: A systematic review of the literature. Obes Rev 2008;9:474-488.

45. Kelley CP, Sbrocco G, Sbrocco T. Behavioral modification for the management of obesity. Prim Care 2016;43: 159-175, x.

46. Saunders TJ, Chaput JP, Tremblay MS. Sedentary behaviour as an emerging risk factor for cardiometabolic diseases in children and youth. Can J Diabetes 2014;38: 53-61.

47. Must A, Jacques PF, Dallal GE, et al. Long-term morbidity and mortality of overweight adolescents. A followup of the Harvard Growth Study of 1922 to 1935. N Engl J Med 1992;327:1350-1355.

48. Vanhecke TE, Miller WM, Franklin BA, et al. Awareness, knowledge, and perception of heart disease among adolescents. Eur J Cardiovasc Prev Rehabil 2006;13:718-723.

49. Colafella KMM, Denton KM. Sex-specific differences in hypertension and associated cardiovascular disease. Nat Rev Nephrol 2018;14:185-201.

50. Benjamin EJ, Blaha MJ, Chiuve SE, et al. Heart disease and stroke statistics-2017 update: A Report From the American Heart Association. Circulation 2017;135:e146-e603.

51. Wilson PW, D’Agostino RB, Sullivan L, et al. Overweight and obesity as determinants of cardiovascular risk: The Framingham experience. Arch Intern Med 2002;162: 1867-1872.

52. Wilmot KA, O'Flaherty M, Capewell S, et al. Coronary heart disease mortality declines in the United States from 1979 through 2011: Evidence for stagnation in young adults, especially women. Circulation 2015;132:9971002.

53. Windham BG, Fumagalli S, Ble A, et al. The relationship between heart rate variability and adiposity differs for central and overall adiposity. J Obes 2012;2012:149516. 
54. Zahorska-Markiewicz B, Kuagowska E, Kucio C, et al. Heart rate variability in obesity. Int J Obes Relat Metab Disord 1993;17:21-23.

55. Karason K, Molgaard H, Wikstrand J, et al. Heart rate variability in obesity and the effect of weight loss. Am J Cardiol 1999;83:1242-1247.

56. Yadav RL, Yadav PK, Yadav LK, et al. Association between obesity and heart rate variability indices: An intuition toward cardiac autonomic alteration-A risk of CVD. Diabetes Metab Syndr Obes 2017;10:57-64.

57. Rask-Madsen C, Kahn CR. Tissue-specific insulin signaling, metabolic syndrome, and cardiovascular disease. Arterioscler Thromb Vasc Biol 2012;32:2052-2059.

58. Thorp AA, Schlaich MP. Relevance of sympathetic nervous system activation in obesity and metabolic syndrome. J Diabetes Res 2015;2015:341583.

59. Cassaglia PA, Hermes SM, Aicher SA, et al. Insulin acts in the arcuate nucleus to increase lumbar sympathetic nerve activity and baroreflex function in rats. $J$ Physiol 2011;589(Pt 7):1643-1662.

60. Lambert GW, Straznicky NE, Lambert EA, et al. Sympathetic nervous activation in obesity and the metabolic syndrome-Causes, consequences and therapeutic implications. Pharmacol Ther 2010;126:159-172.

61. Upadhyay RK. Emerging risk biomarkers in cardiovascular diseases and disorders. J Lipids 2015;2015:971453.

62. Ahn N, Kim K. High-density lipoprotein cholesterol (HDL-C) in cardiovascular disease: Effect of exercise training. Integr Med Res 2016;5:212-215.

63. Lawes CM, Vander Hoorn S, Rodgers A. International Society of H., Global burden of blood-pressure-related disease, 2001. Lancet 2008;371:1513-1518.

64. Rapsomaniki E, Timmis A, George J, et al. Blood pressure and incidence of twelve cardiovascular diseases: Lifetime risks, healthy life-years lost, and age-specific associations in 1.25 million people. Lancet 2014;383:1899-1911.

65. Whelton PK, Carey RM, Aronow WS, et al. 2017 ACC/ AHA/AAPA/ABC/ACPM/AGS/APhA/ASH/ASPC/NMA/ PCNA Guideline for the Prevention, Detection, Evaluation, and Management of High Blood Pressure in Adults: A Report of the American College of Cardiology/American Heart Association Task Force on Clinical Practice Guidelines. Hypertension 2018;71:e13-e115.

66. Angeli F, Reboldi G, Verdecchia P. Hypertension, inflammation and atrial fibrillation. J Hypertens 2014;32: 480-483.

67. Khot UN, Khot MB, Bajzer CT, et al. Prevalence of conventional risk factors in patients with coronary heart disease. JAMA 2003;290:898-904.

68. Flynn JT, Kaelber DC, Baker-Smith CM, et al. Clinical Practice Guideline for Screening and Management of High Blood Pressure in Children and Adolescents. Pediatrics 2017;140:e20171904.

69. Turer CB, Brady TM, de Ferranti SD. Obesity, hypertension, and dyslipidemia in childhood are key modifiable antecedents of adult cardiovascular disease: A call to action. Circulation 2018;137:1256-1259.

70. Skinner AC, Perrin EM, Moss LA, et al. Cardiometabolic risks and severity of obesity in children and young adults. N Engl J Med 2015;373:1307-1317.

71. Cook S, Kavey RE. Dyslipidemia and pediatric obesity. Pediatr Clin North Am 2011;58:1363-1373, ix.

72. Gomez-Diaz RA, Wacher-Rodarte NH. [Childhood obesity and dyslipidemia]. Rev Med Inst Mex Seguro Soc 2014;52 Suppl 1:S102-S108.
73. Koskinen J, Juonala M, Dwyer T, et al. Impact of lipid measurements in youth in addition to conventional clinicbased risk factors on predicting preclinical atherosclerosis in adulthood: International childhood cardiovascular cohort consortium. Circulation 2018;137:1246-1255.

74. Roberts CK, Sindhu KK. Oxidative stress and metabolic syndrome. Life Sci 2009;84:705-712.

75. Hutcheson R, Rocic P. The metabolic syndrome, oxidative stress, environment, and cardiovascular disease: The great exploration. Exp Diabetes Res 2012;2012:271028.

76. Manna P, Jain SK. Obesity, oxidative stress, adipose tissue dysfunction, and the associated health risks: Causes and therapeutic strategies. Metab Syndr Relat Disord 2015;13:423-444.

77. Rains JL, Jain SK. Oxidative stress, insulin signaling, and diabetes. Free Radic Biol Med 2011;50:567-575.

78. Kunsch C, Medford RM. Oxidative stress as a regulator of gene expression in the vasculature. Circ Res 1999;85:753766.

79. Vichova T, Motovska Z. Oxidative stress: Predictive marker for coronary artery disease. Exp Clin Cardiol 2013;18:e88-e91.

80. Holvoet P. Relations between metabolic syndrome, oxidative stress and inflammation and cardiovascular disease. Verh K Acad Geneeskd Belg 2008;70:193-219.

81. Hori M, Nishida K. Oxidative stress and left ventricular remodelling after myocardial infarction. Cardiovasc Res 2009;81:457-464.

82. Siwik DA, Colucci WS. Regulation of matrix metalloproteinases by cytokines and reactive oxygen/nitrogen species in the myocardium. Heart Fail Rev 2004;9:43-51.

83. Cervantes Gracia K, Llanas-Cornejo D, Husi H. CVD and oxidative stress. J Clin Med 2017;6:22.

84. Griendling KK, Minieri CA, Ollerenshaw JD, et al. Angiotensin II stimulates NADH and NADPH oxidase activity in cultured vascular smooth muscle cells. Circ Res 1994;74:1141-1148.

85. Rajagopalan S, Kurz S, Munzel T, et al. Angiotensin IImediated hypertension in the rat increases vascular superoxide production via membrane NADH/NADPH oxidase activation. Contribution to alterations of vasomotor tone. J Clin Invest 1996;97:1916-1923.

86. Griendling KK, FitzGerald GA. Oxidative stress and cardiovascular injury: Part I: Basic mechanisms and in vivo monitoring of ROS. Circulation 2003;108:19121916.

87. Sugamura K, Keaney JF, Jr. Reactive oxygen species in cardiovascular disease. Free Radic Biol Med 2011;51: 978-992.

88. Ho E, Karimi Galougahi K, Liu CC, et al. Biological markers of oxidative stress: Applications to cardiovascular research and practice. Redox Biol 2013;1:483-491.

89. Nagy E, Jermendy AL, Merkely B, et al. Clinical importance of epicardial adipose tissue. Arch Med Sci 2017;13: 864-874.

90. Iozzo P. Myocardial, perivascular, and epicardial fat. Diabetes Care 2011;34 Suppl 2:S371-S379.

91. Wu Y, Zhang A, Hamilton DJ, et al. Epicardial fat in the maintenance of cardiovascular health. Methodist Debakey Cardiovasc J 2017;13:20-24.

92. Bertaso AG, Bertol D, Duncan BB, et al. Epicardial fat: Definition, measurements and systematic review of main outcomes. Arq Bras Cardiol 2013;101:e18-e28.

93. Meenakshi K, Rajendran M, Srikumar S, et al. Epicardial fat thickness: A surrogate marker of coronary artery dis- 
ease-Assessment by echocardiography. Indian Heart $J$ 2016;68:336-341.

94. Gulgun M, Genc FA. Measurement of epicardial fat thickness by echocardiography presents challenges. Arq Bras Cardiol 2016;107:497-498.

95. Seven E, Husemoen LL, Sehested TS, et al. Adipocytokines, C-reactive protein, and cardiovascular disease: A population-based prospective study. PLoS One 2015;10: e0128987.

96. Van de Voorde J, Pauwels B, Boydens C, et al. Adipocytokines in relation to cardiovascular disease. Metabolism 2013;62:1513-1521.

97. Golia E, Limongelli G, Natale F, et al. Adipose tissue and vascular inflammation in coronary artery disease. World $J$ Cardiol 2014;6:539-554.

98. Mattu HS, Randeva HS. Role of adipokines in cardiovascular disease. J Endocrinol 2013;216:T17-T36.

99. Cao H. Adipocytokines in obesity and metabolic disease. J Endocrinol 2014;220:T47-T59.

100. Shibata R, Murohara T, Ouchi N. Protective role of adiponectin in cardiovascular disease. Curr Med Chem 2012; 19:5459-5466.

101. Goldstein BJ, Scalia RG, Ma XL. Protective vascular and myocardial effects of adiponectin. Nat Clin Pract Cardiovasc Med 2009;6:27-35.

102. Ebrahimi-Mamaeghani M, Mohammadi S, Arefhosseini SR, et al. Adiponectin as a potential biomarker of vascular disease. Vasc Health Risk Manag 2015;11:55-70.

103. Achari AE, Jain SK. Adiponectin, a therapeutic target for obesity, diabetes, and endothelial dysfunction. Int $\mathrm{J} \mathrm{Mol}$ Sci 2017;18:E1321.

104. Lowe G, Woodward M, Hillis G, et al. Circulating inflammatory markers and the risk of vascular complications and mortality in people with type 2 diabetes and cardiovascular disease or risk factors: The ADVANCE study. Diabetes 2014;63:1115-1123.

105. Alberti KG, Zimmet P, Shaw J. Metabolic syndrome-A new world-wide definition. A Consensus Statement from the International Diabetes Federation. Diabet Med 2006; 23:469-480.

106. Shen J, Zhang J, Wen J, et al. Correlation of serum alanine aminotransferase and aspartate aminotransferase with coronary heart disease. Int J Clin Exp Med 2015;8:4399-4404.

107. Al-Hadi HA, Fox KA. Cardiac markers in the early diagnosis and management of patients with acute coronary syndrome. Sultan Qaboos Univ Med J 2009;9:231-246.

108. Mohiuddin SM, Raffetto J, Sketch MH, et al. LDH isoenzymes and myocardial infarction in patients undergoing coronary bypass surgery: An excellent correlation. Am Heart J 1976;92:584-588.

109. Lott JA, Stang JM. Serum enzymes and isoenzymes in the diagnosis and differential diagnosis of myocardial ischemia and necrosis. Clin Chem 1980;26:1241-1250.

110. Mythili S, Malathi N. Diagnostic markers of acute myocardial infarction. Biomed Rep 2015;3:743-748.

111. Kutsal A, Saydam GS, Yucel D, et al. Changes in the serum levels of CK-MB, LDH, LDH1, SGOT and myoglobin due to cardiac surgery. J Cardiovasc Surg (Torino) 1991;32:516-522.

112. Ruppert M, Van Hee R. Creatinine-kinase-MB determination in non-cardiac trauma: Its difference with cardiac infarction and its restricted use in trauma situations. Eur $J$ Emerg Med 2001;8:177-179.

113. Villablanca PA, Vlismas PP, Aleksandrovich T, et al. Case report and systematic review of pulmonary embo- lism mimicking ST-elevation myocardial infarction. Vascular 2019;27:90-97.

114. Ghatak A, Alsulaimi A, Acosta YM, et al. Acute pulmonary embolism masquerading as acute myocardial infarction. Proc (Bayl Univ Med Cent) 2015;28:69-70.

115. Sinner MF, Wang N, Fox CS, et al. Relation of circulating liver transaminase concentrations to risk of new-onset atrial fibrillation. Am J Cardiol 2013;111:219-224.

116. Yun KE, Shin CY, Yoon YS, et al. Elevated alanine aminotransferase levels predict mortality from cardiovascular disease and diabetes in Koreans. Atherosclerosis 2009;205:533-537.

117. Schindhelm RK, Dekker JM, Nijpels G, et al. Alanine aminotransferase predicts coronary heart disease events: A 10-year follow-up of the Hoorn Study. Atherosclerosis 2007;191:391-396.

118. Johnston CC, Bolton EC. Cardiac enzymes. Ann Emerg Med 1982;11:27-35.

119. Boyde TR, Kwong EM. Aspartate aminotransferase isoenzymes-Differential kinetic assay in serum. Clin Chim Acta 1983;128:95-102.

120. Boyde TR. Serum levels of the mitochondrial isoenzym of aspartate aminotransferase in myocardial infarction and muscular dystrophy. Enzymol Biol Clin (Basel) 1968;9: 385-392.

121. Rabkin SW, Desjardins P. Mitochondrial and cytoplasmic isoenzymes of aspartate aminotransferase in sera of patients after myocardial infarction. Clin Chim Acta 1984; 138:245-257.

122. Panteghini M, Pagani F, Cuccia C. Activity of serum aspartate aminotransferase isoenzymes in patients with acute myocardial infarction. Clin Chem 1987;33:67-71.

123. Ioannou GN, Weiss NS, Boyko EJ, et al. Elevated serum alanine aminotransferase activity and calculated risk of coronary heart disease in the United States. Hepatology 2006;43:1145-1151.

124. Killip T, 3rd, Payne MA. High serum transaminase activity in heart disease. Circulatory failure and hepatic necrosis. Circulation 1960;21:646-660.

125. Arinc H, Sarli B, Baktir AO, et al. Serum gamma glutamyl transferase and alanine transaminase concentrations predict endothelial dysfunction in patients with non-alcoholic steatohepatitis. Ups J Med Sci 2013;118:228-234.

126. Ballestri S, Lonardo A, Bonapace S, et al. Risk of cardiovascular, cardiac and arrhythmic complications in patients with non-alcoholic fatty liver disease. World $J$ Gastroenterol 2014;20:1724-1745.

127. Gao M, Cheng Y, Zheng Y, et al. Association of serum transaminases with short- and long-term outcomes in patients with ST-elevation myocardial infarction undergoing primary percutaneous coronary intervention. BMC Cardiovasc Disord 2017;17:43.

128. Ruzich RS. Cardiac enzymes. How to use serial determinations to confirm acute myocardial infarction. Postgrad Med 1992;92:85-89, 92.

129. Weinberger I, Rotenberg Z, Sagie A, et al. "Flipped" lactic dehydrogenase pattern in acute coronary insufficiency. Clin Cardiol 1986;9:597-599.

130. Wroblewski F, Ross C, Gregory K. Isoenzymes and myocardial infarction. N Engl J Med 1960;263:531-536.

131. Konttinen A. alpha-Hydroxybutyric dehydrogenase in the detection of myocardial infarction. Lancet 1961;2:556.

132. Penttila I, Penttila K, Rantanen T. Laboratory diagnosis of patients with acute chest pain. Clin Chem Lab Med 2000; 38:187-197. 
133. Kato GJ, McGowan V, Machado RF, et al. Lactate dehydrogenase as a biomarker of hemolysis-associated nitric oxide resistance, priapism, leg ulceration, pulmonary hypertension, and death in patients with sickle cell disease. Blood 2006;107:2279-2285.

134. Martins JT, Li DJ, Baskin LB, et al. Comparison of cardiac troponin I and lactate dehydrogenase isoenzymes for the late diagnosis of myocardial injury. Am J Clin Pathol 1996;106:705-708.

135. Guzy PM. Creatine phosphokinase-MB (CPK-MB) and the diagnosis of myocardial infarction. West J Med 1977; 127:455-460.

136. Schlattner U, Tokarska-Schlattner M, Wallimann T. Mitochondrial creatine kinase in human health and disease. Biochim Biophys Acta 2006;1762:164-180.

137. Moghadam-Kia S, Oddis CV, Aggarwal R. Approach to asymptomatic creatine kinase elevation. Cleve Clin J Med 2016;83:37-42.

138. Mair J, Artner-Dworzak E, Dienstl A, et al. Early detection of acute myocardial infarction by measurement of mass concentration of creatine kinase-MB. Am J Cardiol 1991;68:1545-1550.

139. Puleo PR, Meyer D, Wathen C, et al. Use of a rapid assay of subforms of creatine kinase MB to diagnose or rule out acute myocardial infarction. N Engl J Med 1994;331:561-566.

140. Khadjieva Z, Akhmedova DI, Akhmedova NR. The role of activity creatine phosphokinase MB (CPK-MB) in the prognosis of cardiomyopathy in children. Pediatr Ther 2017;7(4 (Suppl)):40.

141. Danese E, Montagnana M. An historical approach to the diagnostic biomarkers of acute coronary syndrome. Ann Transl Med 2016;4:194.

142. Adams JE, 3rd, Abendschein DR, Jaffe AS. Biochemical markers of myocardial injury. Is MB creatine kinase the choice for the 1990s? Circulation 1993;88:750-763.

143. Gibler WB, Gibler CD, Weinshenker E, et al. Myoglobin as an early indicator of acute myocardial infarction. Ann Emerg Med 1987;16:851-856.

144. Bastagli L, Guardigli G, Ruffini M, et al. [Changes in plasma myoglobin levels in ischemic heart disease]. G Clin Med 1989;70:733-735, 739-742.

145. Ohman EM, Casey C, Bengtson JR, et al. Early detection of acute myocardial infarction: Additional diagnostic information from serum concentrations of myoglobin in patients without ST elevation. Br Heart J 1990;63:335-338.

146. Katus HA, Diederich KW, Scheffold T, et al. Noninvasive assessment of infarct reperfusion: The predictive power of the time to peak value of myoglobin, CKMB, and CK in serum. Eur Heart J 1988;9:619-624.

147. Ellis AK, Little T, Masud AR, et al. Early noninvasive detection of successful reperfusion in patients with acute myocardial infarction. Circulation 1988;78:1352-1357.

148. Plebani M, Zaninotto M. Diagnostic strategies using myoglobin measurement in myocardial infarction. Clin Chim Acta 1998;272:69-77.

149. Newgard CB, Hwang PK, Fletterick RJ. The family of glycogen phosphorylases: Structure and function. Crit Rev Biochem Mol Biol 1989;24:69-99.

150. Kato K, Shimizu A, Kurobe N, et al. Human brain-type glycogen phosphorylase: Quantitative localization in human tissues determined with an immunoassay system. J Neurochem 1989;52:1425-1432.

151. Mair J. Glycogen phosphorylase isoenzyme BB to diagnose ischaemic myocardial damage. Clin Chim Acta 1998; 272:79-86.
152. Rabitzsch G, Mair J, Lechleitner P, et al. Isoenzyme BB of glycogen phosphorylase $\mathrm{b}$ and myocardial infarction. Lancet 1993;341:1032-1033.

153. Cubranic Z, Madzar Z, Matijevic S, et al. Diagnostic accuracy of heart fatty acid binding protein (H-FABP) and glycogen phosphorylase isoenzyme BB (GPBB) in diagnosis of acute myocardial infarction in patients with acute coronary syndrome. Biochem Med (Zagreb) 2012;22:225-236.

154. Lee J, Romero R, Dong Z, et al. Glycogen phosphorylase isoenzyme $\mathrm{BB}$ plasma concentration is elevated in pregnancy and preterm preeclampsia. Hypertension 2012;59: 274-282.

155. Lippi G, Mattiuzzi C, Comelli I, et al. Glycogen phosphorylase isoenzyme BB in the diagnosis of acute myocardial infarction: A meta-analysis. Biochem Med (Zagreb) 2013;23:78-82.

156. Apple FS, Wu AH, Mair J, et al. Future biomarkers for detection of ischemia and risk stratification in acute coronary syndrome. Clin Chem 2005;51:810-824.

157. Peetz D, Post F, Schinzel H, et al. Glycogen phosphorylase BB in acute coronary syndromes. Clin Chem Lab Med 2005;43:1351-1358.

158. Rabitzsch G, Mair J, Lechleitner P, et al. Immunoenzymometric assay of human glycogen phosphorylase isoenzyme BB in diagnosis of ischemic myocardial injury. Clin Chem 1995;41:966-978.

159. Bhardwaj A, Januzzi JL, Jr. ST2: A novel biomarker for heart failure. Expert Rev Mol Diagn 2010;10:459-464.

160. Weinberg EO, Shimpo M, De Keulenaer GW, et al. Expression and regulation of ST2, an interleukin-1 receptor family member, in cardiomyocytes and myocardial infarction. Circulation 2002;106:2961-2966.

161. Januzzi JL, Jr., Peacock WF, Maisel AS, et al. Measurement of the interleukin family member ST2 in patients with acute dyspnea: Results from the PRIDE (Pro-Brain Natriuretic Peptide Investigation of Dyspnea in the Emergency Department) study. J Am Coll Cardiol 2007; 50:607-613.

162. Benoit JL, Hicks CW, Engineer RS, et al. ST2 in emergency department patients with noncardiac dyspnea. Acad Emerg Med 2013;20:1207-1210.

163. Dieplinger B, Egger M, Haltmayer M, et al. Increased soluble ST2 predicts long-term mortality in patients with stable coronary artery disease: Results from the Ludwigshafen risk and cardiovascular health study. Clin Chem 2014;60:530-540.

164. Rehman SU, Mueller T, Januzzi JL, Jr. Characteristics of the novel interleukin family biomarker ST2 in patients with acute heart failure. J Am Coll Cardiol 2008;52:14581465 .

165. Boisot S, Beede J, Isakson S, et al. Serial sampling of ST2 predicts 90-day mortality following destabilized heart failure. J Card Fail 2008;14:732-738.

166. Xu SD, Su GH, Lu YX, et al. Elevated soluble ST2 and depression increased the risk of all-cause mortality and hospitalization in patients with heart failure. Int Heart $J$ 2014;55:445-450.

167. Dieplinger B, Januzzi JL, Jr., Steinmair M, et al. Analytical and clinical evaluation of a novel high-sensitivity assay for measurement of soluble ST2 in human plasmaThe Presage ST2 assay. Clin Chim Acta 2009;409:33-40.

168. Aldous SJ, Richards AM, Troughton R, et al. ST2 has diagnostic and prognostic utility for all-cause mortality and heart failure in patients presenting to the emergency department with chest pain. J Card Fail 2012;18:304-310. 
169. Bayes-Genis A, Pascual-Figal D, Januzzi JL, et al. Soluble ST2 monitoring provides additional risk stratification for outpatients with decompensated heart failure. Rev Esp Cardiol 2010;63:1171-1178.

170. Chawla R, Goyal N, Calton R, et al. Ischemia modified albumin: A novel marker for acute coronary syndrome. Indian J Clin Biochem 2006;21:77-82.

171. Bhakthavatsala Reddy C, Cyriac C, Desle HB. Role of "Ischemia Modified Albumin" (IMA) in acute coronary syndromes. Indian Heart J 2014;66:656-662.

172. Wahab M. Ischemia modified albumin (IMA) in acute coronary syndrome (ACS) and left bundle branch block (LBBB). Does it make the difference? Egypt Heart $J$ 2017;69:183-190.

173. Sbarouni E, Georgiadou P, Kremastinos DT, et al. Ischemia modified albumin: Is this marker of ischemia ready for prime time use? Hellenic J Cardiol 2008;49:260-266.

174. Apple FS. Clinical and analytical review of ischemiamodified albumin measured by the albumin cobalt binding test. Adv Clin Chem 2005;39:1-10.

175. Oh BJ, Seo MH, Kim HS. Insignificant role of the Nterminal cobalt-binding site of albumin in the assessment of acute coronary syndrome: Discrepancy between the albumin cobalt-binding assay and N-terminal-targeted immunoassay. Biomarkers 2012;17:394-401.

176. Oran I, Oran B. Ischemia-modified albumin as a marker of acute coronary syndrome: The case for revising the concept of "N-Terminal Modification" to "Fatty Acid Occupation" of albumin. Dis Markers 2017;2017:5692583.

177. Can M, Varlibas F, Guven B, et al. Ischemia modified albumin and plasma oxidative stress markers in Alzheimer's disease. Eur Neurol 2013;69:377-380.

178. Bhagavan NV, Ha JS, Park JH, et al. Utility of serum Fatty Acid concentrations as a marker for acute myocardial infarction and their potential role in the formation of ischemia-modified albumin: A pilot study. Clin Chem 2009;55:1588-1590.

179. Blindauer CA, Khazaipoul S, Yu R, et al. Fatty Acidmediated inhibition of metal binding to the multi-metal site on serum albumin: Implications for cardiovascular disease. Curr Top Med Chem 2016;16:3021-3032.

180. Coverdale JPC, Katundu KGH, Sobczak AIS, et al. Ischemia-modified albumin: Crosstalk between fatty acid and cobalt binding. Prostaglandins Leukot Essent Fatty Acids 2018;135:147-157.

181. Babuin L, Jaffe AS. Troponin: The biomarker of choice for the detection of cardiac injury. CMAJ 2005;173:11911202.

182. Katus HA, Remppis A, Scheffold T, et al. Intracellular compartmentation of cardiac troponin $\mathrm{T}$ and its release kinetics in patients with reperfused and nonreperfused myocardial infarction. Am J Cardiol 1991;67:1360-1367.

183. Katus HA, Remppis A, Neumann FJ, et al. Diagnostic efficiency of troponin T measurements in acute myocardial infarction. Circulation 1991;83:902-912.

184. Thygesen K, Alpert JS, Jaffe AS, et al. Third universal definition of myocardial infarction. Circulation 2012;126: 2020-2035.

185. Lippi G. Biomarkers: Novel troponin immunoassay for early ACS rule-out. Nat Rev Cardiol 2016;13:9-10.

186. Patil H, Vaidya O, Bogart D. A review of causes and systemic approach to cardiac troponin elevation. Clin Cardiol 2011;34:723-728.

187. Lim GB. Biomarkers: Sensitivity of troponins for diagnosis and risk prediction. Nat Rev Cardiol 2016;13:441.
188. Brown NK, Zhou Z, Zhang J, et al. Perivascular adipose tissue in vascular function and disease: A review of current research and animal models. Arterioscler Thromb Vasc Biol 2014;34:1621-1630.

189. Levin ER, Gardner DG, Samson WK. Natriuretic peptides. N Engl J Med 1998;339:321-328.

190. Mukoyama M, Nakao K, Hosoda K, et al. Brain natriuretic peptide as a novel cardiac hormone in humans. Evidence for an exquisite dual natriuretic peptide system, atrial natriuretic peptide and brain natriuretic peptide. J Clin Invest 1991;87:1402-1412.

191. Volpe M, Carnovali M, Mastromarino V. The natriuretic peptides system in the pathophysiology of heart failure: From molecular basis to treatment. Clin Sci (Lond) 2016; 130:57-77.

192. Yandle TG, Richards AM. B-type Natriuretic Peptide circulating forms: Analytical and bioactivity issues. Clin Chim Acta 2015;448:195-205.

193. Daniels LB, Maisel AS. Natriuretic peptides. J Am Coll Cardiol 2007;50:2357-2368.

194. Moro C, Smith SR. Natriuretic peptides: New players in energy homeostasis. Diabetes 2009;58:2726-2728.

195. Potter LR. Natriuretic peptide metabolism, clearance and degradation. FEBS J 2011;278:1808-1817.

196. Yan W, Wu F, Morser J, et al. Corin, a transmembrane cardiac serine protease, acts as a pro-atrial natriuretic peptide-converting enzyme. Proc Natl Acad Sci U S A 2000;97:8525-8529.

197. Dietz JR. Mechanisms of atrial natriuretic peptide secretion from the atrium. Cardiovasc Res 2005;68:8-17.

198. Lew RA, Baertschi AJ. Mechanisms of hypoxia-induced atrial natriuretic factor release from rat hearts. Am J Physiol 1989;257(1 Pt 2):H147-H156.

199. Chen BN, Rayner TE, Menadue MF, et al. Effect of ischaemia and role of eicosanoids in release of atrial natriuretic factor from rat heart. Cardiovasc Res 1993;27: 1576-1579.

200. Abassi Z, Karram T, Ellaham S, et al. Implications of the natriuretic peptide system in the pathogenesis of heart failure: Diagnostic and therapeutic importance. Pharmacol Ther 2004;102:223-241.

201. Lerman A, Gibbons RJ, Rodeheffer RJ, et al. Circulating N-terminal atrial natriuretic peptide as a marker for symptomless left-ventricular dysfunction. Lancet 1993; 341:1105-1109.

202. Gaggin HK, Januzzi JL, Jr. Biomarkers and diagnostics in heart failure. Biochim Biophys Acta 2013;1832:2442-2450.

203. Maisel A, Mueller C, Nowak R, et al. Mid-region prohormone markers for diagnosis and prognosis in acute dyspnea: Results from the BACH (Biomarkers in Acute Heart Failure) trial. J Am Coll Cardiol 2010;55:20622076.

204. Shah RV, Truong QA, Gaggin HK, et al. Mid-regional pro-atrial natriuretic peptide and pro-adrenomedullin testing for the diagnostic and prognostic evaluation of patients with acute dyspnoea. Eur Heart J 2012;33:21972205.

205. Lindberg S, Jensen JS, Pedersen SH, et al. MR-proANP improves prediction of mortality and cardiovascular events in patients with STEMI. Eur J Prev Cardiol 2015; 22:693-700.

206. Darche FF, Baumgartner C, Biener M, et al. Comparative accuracy of NT-proBNP and MR-proANP for the diagnosis of acute heart failure in dyspnoeic patients. ESC Heart Fail 2017;4:232-240. 
207. Seilhamer JJ, Arfsten A, Miller JA, et al. Human and canine gene homologs of porcine brain natriuretic peptide. Biochem Biophys Res Commun 1989;165:650-658.

208. Horwich TB, Hamilton MA, Fonarow GC. B-type natriuretic peptide levels in obese patients with advanced heart failure. J Am Coll Cardiol 2006;47:85-90.

209. Maisel A, Mueller C, Adams K, Jr., et al. State of the art: Using natriuretic peptide levels in clinical practice. Eur $J$ Heart Fail 2008;10:824-839.

210. McMurray JJ, Adamopoulos S, Anker SD, et al. ESC guidelines for the diagnosis and treatment of acute and chronic heart failure 2012: The Task Force for the Diagnosis and Treatment of Acute and Chronic Heart Failure 2012 of the European Society of Cardiology. Developed in collaboration with the Heart Failure Association (HFA) of the ESC. Eur J Heart Fail 2012;14:803-869.

211. Islam YF, Joseph R, Chowdhury RR, et al. Heart failure induced by perinatal ablation of cardiac myosin light chain kinase. Front Physiol 2016;7:480.

212. Schmaltz AA. Chronic congestive heart failure in infancy and childhood: New aspects of diagnosis and treatment. Klin Padiatr 2015;227:3-9.

213. Nir A, Lindinger A, Rauh M, et al. NT-pro-B-type natriuretic peptide in infants and children: Reference values based on combined data from four studies. Pediatr Cardiol 2009;30:3-8.

214. Boerrigter G, Costello-Boerrigter LC, Burnett JC, Jr. Natriuretic peptides in the diagnosis and management of chronic heart failure. Heart Fail Clin 2009;5:501-514.

215. Brandt I, Lambeir AM, Ketelslegers JM, et al. Dipeptidylpeptidase IV converts intact B-type natriuretic peptide into its des-SerPro form. Clin Chem 2006;52:82-87.

216. Niederkofler EE, Kiernan UA, O'Rear J, et al. Detection of endogenous B-type natriuretic peptide at very low concentrations in patients with heart failure. Circ Heart Fail 2008;1:258-264.

217. Boerrigter G, Costello-Boerrigter LC, Harty GJ, et al. Des-serine-proline brain natriuretic peptide 3-32 in cardiorenal regulation. Am J Physiol Regul Integr Comp Physiol 2007;292:R897-R901.

218. Mangiafico S, Costello-Boerrigter LC, Andersen IA, et al. Neutral endopeptidase inhibition and the natriuretic peptide system: An evolving strategy in cardiovascular therapeutics. Eur Heart J 2013;34:886-893c.

219. Fielitz J, Dendorfer A, Pregla R, et al. Neutral endopeptidase is activated in cardiomyocytes in human aortic valve stenosis and heart failure. Circulation 2002;105: 286-289.

220. Hagiwara H, Sakaguchi H, Itakura M, et al. Autocrine regulation of rat chondrocyte proliferation by natriuretic peptide $\mathrm{C}$ and its receptor, natriuretic peptide receptor-B. J Biol Chem 1994;269:10729-10733.

221. Hagiwara H, Sakaguchi H, Lodhi KM, et al. Subtype switching of natriuretic peptide receptors in rat chondrocytes during in vitro culture. J Biochem 1994;116:606-609.

222. Suga S, Nakao K, Itoh $\mathrm{H}$, et al. Endothelial production of C-type natriuretic peptide and its marked augmentation by transforming growth factor-beta. Possible existence of "vascular natriuretic peptide system." J Clin Invest 1992; 90:1145-1149.

223. Wang Y, de Waard MC, Sterner-Kock A, et al. Cardiomyocyte-restricted over-expression of C-type natriuretic peptide prevents cardiac hypertrophy induced by myocardial infarction in mice. Eur J Heart Fail 2007;9: $548-557$.
224. Lumsden NG, Khambata RS, Hobbs AJ. C-type natriuretic peptide (CNP): Cardiovascular roles and potential as a therapeutic target. Curr Pharm Des 2010;16:4080-4088.

225. Wu C, Wu F, Pan J, et al. Furin-mediated processing of Pro-C-type natriuretic peptide. J Biol Chem 2003;278: 25847-25852.

226. Totsune K, Takahashi K, Ohneda M, et al. C-type natriuretic peptide in the human central nervous system: Distribution and molecular form. Peptides 1994;15:37-40.

227. Stingo AJ, Clavell AL, Heublein DM, et al. Presence of Ctype natriuretic peptide in cultured human endothelial cells and plasma. Am J Physiol 1992;263(4 Pt 2):H1318H1321.

228. Minamino N, Makino Y, Tateyama H, et al. Characterization of immunoreactive human $\mathrm{C}$-type natriuretic peptide in brain and heart. Biochem Biophys Res Commun 1991;179:535-542.

229. Yeung VT, Ho SK, Nicholls MG, et al. Binding of CNP22 and CNP-53 to cultured mouse astrocytes and effects on cyclic GMP. Peptides 1996;17:101-106.

230. Wei CM, Heublein DM, Perrella MA, et al. Natriuretic peptide system in human heart failure. Circulation 1993; 88:1004-1009.

231. Seguchi O, Takashima S, Yamazaki S, et al. A cardiac myosin light chain kinase regulates sarcomere assembly in the vertebrate heart. J Clin Invest 2007;117:2812-2824.

232. Taniguchi M, Okamoto R, Ito M, et al. New isoform of cardiac myosin light chain kinase and the role of cardiac myosin phosphorylation in alpha1-adrenoceptor mediated inotropic response. PLoS One 2015;10:e0141130.

233. Chang AN, Battiprolu PK, Cowley PM, et al. Constitutive phosphorylation of cardiac myosin regulatory light chain in vivo. J Biol Chem 2015;290:10703-10716.

234. Kampourakis T, Sun YB, Irving M. Myosin light chain phosphorylation enhances contraction of heart muscle via structural changes in both thick and thin filaments. Proc Natl Acad Sci U S A 2016;113:E3039-E3047.

235. Ding P, Huang J, Battiprolu PK, et al. Cardiac myosin light chain kinase is necessary for myosin regulatory light chain phosphorylation and cardiac performance in vivo. J Biol Chem 2010;285:40819-40829.

236. Chang AN, Mahajan P, Knapp S, et al. Cardiac myosin light chain is phosphorylated by $\mathrm{Ca} 2+/$ calmodulindependent and -independent kinase activities. Proc Natl Acad Sci U S A 2016;113:E3824-E3833.

237. Warren SA, Briggs LE, Zeng H, et al. Myosin light chain phosphorylation is critical for adaptation to cardiac stress. Circulation 2012;126:2575-2588.

238. Sheikh F, Lyon RC, Chen J. Getting the skinny on thick filament regulation in cardiac muscle biology and disease. Trends Cardiovasc Med 2014;24:133-141.

239. Sheikh F, Ouyang K, Campbell SG, et al. Mouse and computational models link Mlc2v dephosphorylation to altered myosin kinetics in early cardiac disease. J Clin Invest 2012;122:1209-1221.

240. Scruggs SB, Solaro RJ. The significance of regulatory light chain phosphorylation in cardiac physiology. Arch Biochem Biophys 2011;510:129-134.

241. Massengill MT, Ashraf HM, Chowdhury RR, et al. Acute heart failure with cardiomyocyte atrophy induced in adult mice by ablation of cardiac myosin light chain kinase. Cardiovasc Res 2016;111:34-43.

242. Storch J, McDermott L. Structural and functional analysis of fatty acid-binding proteins. J Lipid Res 2009;50 Suppl: S126-S131. 
243. Tolle A, Jung M, Lein M, et al. Brain-type and liver-type fatty acid-binding proteins: New tumor markers for renal cancer? BMC Cancer 2009;9:248.

244. Ye XD, He Y, Wang S, et al. Heart-type fatty acid binding protein (H-FABP) as a biomarker for acute myocardial injury and long-term post-ischemic prognosis. Acta Pharmacol Sin 2018;39:1155-1163.

245. Das UN. Heart-type fatty acid-binding protein (H-FABP) and coronary heart disease. Indian Heart $J$ 2016;68: 16-18.

246. Boubaker H, Grissa MH, Beltaief K, et al. A new score for the diagnosis of acute coronary syndrome in acute chest pain with non-diagnostic ECG and normal troponin. Emerg Med J 2015;32:764-768.

247. Gami BN, Patel DS, Haridas N, et al. Utility of heart-type fatty acid binding protein as a new biochemical marker for the early diagnosis of acute coronary syndrome. J Clin Diagn Res 2015;9:BC22-BC24.

248. Banu S, Tanveer S, Manjunath CN. Comparative study of high sensitivity troponin $\mathrm{T}$ and heart-type fatty acidbinding protein in STEMI patients. Saudi J Biol Sci 2015; 22:56-61.

249. McMahon CG, Lamont JV, Curtin E, et al. Diagnostic accuracy of heart-type fatty acid-binding protein for the early diagnosis of acute myocardial infarction. Am J Emerg Med 2012;30:267-274.

250. Kabekkodu SP, Mananje SR, Saya RP. A study on the role of heart type fatty acid binding protein in the diagnosis of acute myocardial infarction. J Clin Diagn Res 2016;10: OC07-OC10.

251. Varrone F, Gargano B, Carullo P, et al. The circulating level of FABP3 is an indirect biomarker of microRNA-1. J Am Coll Cardiol 2013;61:88-95.

252. Doenst T, Nguyen TD, Abel ED. Cardiac metabolism in heart failure: Implications beyond ATP production. Circ Res 2013;113:709-724.

253. Neubauer S. The failing heart-An engine out of fuel. $N$ Engl J Med 2007;356:1140-1151.

254. Sack MN, Rader TA, Park S, et al. Fatty acid oxidation enzyme gene expression is downregulated in the failing heart. Circulation 1996;94:2837-2842.

255. Binas B, Danneberg H, McWhir J, et al. Requirement for the heart-type fatty acid binding protein in cardiac fatty acid utilization. FASEB $J$ 1999; 13:805-812.

256. Lamounier-Zepter V, Look C, Alvarez J, et al. Adipocyte fatty acid-binding protein suppresses cardiomyocyte contraction: A new link between obesity and heart disease. Circ Res 2009;105:326-334.

257. Akbal E, Ozbek M, Gunes F, et al. Serum heart type fatty acid binding protein levels in metabolic syndrome. Endocrine 2009;36:433-437.

258. Basar O, Akbal E, Koklu S, et al. Increased H-FABP concentrations in nonalcoholic fatty liver disease. Possible marker for subclinical myocardial damage and subclinical atherosclerosis. Herz 2013;38:417-422.

259. Niizeki T, Takeishi Y, Takabatake N, et al. Circulating levels of heart-type fatty acid-binding protein in a general Japanese population: Effects of age, gender, and physiologic characteristics. Circ J 2007;71:1452-1457.

260. Chen HM, Zheng CX, Gao Q, et al. Heart-type fatty acid binding protein is associated with proteinuria in obesity. PLoS One 2012;7:e45691.

261. Chen K, Chen QJ, Wang LJ, et al. Increment of HFABP level in coronary artery in-stent restenosis segments in diabetic and nondiabetic minipigs: HFABP overexpression promotes multiple pathway-related inflammation, growth and migration in human vascular smooth muscle cells. J Vasc Res 2016;53:27-38.

262. Otaki Y, Watanabe T, Takahashi H, et al. Association of heart-type fatty acid-binding protein with cardiovascular risk factors and all-cause mortality in the general population: The Takahata study. PLoS One 2014;9:e94834.

263. Urbina EM, Williams RV, Alpert BS, et al. Noninvasive assessment of subclinical atherosclerosis in children and adolescents: Recommendations for standard assessment for clinical research: A scientific statement from the American Heart Association. Hypertension 2009;54:919-950.

264. Tardif JC, Heinonen T, Orloff D, et al. Vascular biomarkers and surrogates in cardiovascular disease. Сirculation 2006;113:2936-2942.

265. Kasliwal RR, Bansal M, Desai D, et al. Carotid intimamedia thickness: Current evidence, practices, and Indian experience. Indian J Endocrinol Metab 2014;18:13-22.

266. Baroncini LAV, de Castro Sylvestre L, Filho RP. Carotid intima-media thickness and carotid plaque represent different adaptive responses to traditional cardiovascular risk factors. Int J Cardiol Heart Vasc 2015;9:48-51.

267. Den Ruijter HM, Peters SA, Anderson TJ, et al. Common carotid intima-media thickness measurements in cardiovascular risk prediction: A meta-analysis. JAMA 2012; 308:796-803.

268. Bots ML, Evans GW, Tegeler CH, et al. Carotid intimamedia thickness measurements: Relations with atherosclerosis, risk of cardiovascular disease and application in randomized controlled trials. Chin Med J (Engl) 2016; 129:215-226.

269. Bots ML, Sutton-Tyrrell K. Lessons from the past and promises for the future for carotid intima-media thickness. J Am Coll Cardiol 2012;60:1599-1604.

270. Liu W, Zhang Y, Yu CM, et al. Current understanding of coronary artery calcification. J Geriatr Cardiol 2015;12: 668-675.

271. Kalra SS, Shanahan CM. Vascular calcification and hypertension: Cause and effect. Ann Med 2012;44 Suppl 1: S85-S92.

272. Ibebuogu UN, Ahmadi N, Hajsadeghi F, et al. Measures of coronary artery calcification and association with the metabolic syndrome and diabetes. J Cardiometab Syndr 2009;4:6-11.

273. Okwuosa TM, Greenland P, Burke GL, et al. Prediction of coronary artery calcium progression in individuals with low Framingham Risk Score: The Multi-Ethnic Study of Atherosclerosis. JACC Cardiovasc Imaging 2012;5:144-153.

274. Bacha F, Edmundowicz D, Sutton-Tyrell K, et al. Coronary artery calcification in obese youth: What are the phenotypic and metabolic determinants? Diabetes Care 2014;37:2632-2639.

275. Bissinger A. Cardiac autonomic neuropathy: Why should cardiologists care about that? J Diabetes Res 2017;2017: 5374176.

276. Vinik AI, Erbas T. Diabetic autonomic neuropathy. Handb Clin Neurol 2013;117:279-294.

277. Beijers HJ, Ferreira I, Bravenboer B, et al. Microalbuminuria and cardiovascular autonomic dysfunction are independently associated with cardiovascular mortality: Evidence for distinct pathways: The Hoorn Study. Diabetes Care 2009;32:1698-1703.

278. Baum P, Petroff D, Classen J, et al. Dysfunction of autonomic nervous system in childhood obesity: A crosssectional study. PLoS One 2013;8:e54546. 
279. Kotecha D, New G, Flather MD, et al. Five-minute heart rate variability can predict obstructive angiographic coronary disease. Heart 2012;98:395-401.

280. Tsuji H, Venditti FJ, Jr., Manders ES, et al. Reduced heart rate variability and mortality risk in an elderly cohort. The Framingham Heart Study. Circulation 1994;90:878-883.

281. Riva P, Martini G, Rabbia F, et al. Obesity and autonomic function in adolescence. Clin Exp Hypertens 2001;23: 57-67.

282. Rabbia F, Silke B, Conterno A, et al. Assessment of cardiac autonomic modulation during adolescent obesity. Obes Res 2003;11:541-548.

283. Guizar JM, Ahuatzin R, Amador N, et al. Heart autonomic function in overweight adolescents. Indian Pediatr 2005; 42:464-469.

284. Parish RC, Todman S, Jain SK. Resting heart rate variability, inflammation, and insulin resistance in overweight and obese adolescents. Metab Syndr Relat Disord 2016; 14:291-297.

285. Heart rate variability. Standards of measurement, physiological interpretation, and clinical use. Task Force of the European Society of Cardiology and the North American Society of Pacing and Electrophysiology. Eur Heart J 1996;17:354-381.

286. Akselrod S, Gordon D, Madwed JB, et al. Hemodynamic regulation: Investigation by spectral analysis. Am J Physiol 1985;249(4 Pt 2):H867-H875.

287. Wolf MM, Varigos GA, Hunt D, et al. Sinus arrhythmia in acute myocardial infarction. Med J Aust 1978;2:52-53.

288. La Rovere MT, Bigger JT, Jr., Marcus FI, et al. Baroreflex sensitivity and heart-rate variability in prediction of total cardiac mortality after myocardial infarction. ATRAMI (Autonomic Tone and Reflexes After Myocardial Infarction) Investigators. Lancet 1998;351:478-484.

289. Bigger JT, Jr., Fleiss JL, Steinman RC, et al. Frequency domain measures of heart period variability and mortality after myocardial infarction. Circulation 1992;85:164-171.

290. Hillebrand S, Gast KB, de Mutsert R, et al. Heart rate variability and first cardiovascular event in populations without known cardiovascular disease: Meta-analysis and dose-response meta-regression. Europace 2013;15:742749 .

291. Cygankiewicz I, Zareba W, de Luna AB. Prognostic value of Holter monitoring in congestive heart failure. Cardiol $J$ 2008;15:313-323.

292. Sandercock GR, Brodie DA. The role of heart rate variability in prognosis for different modes of death in chronic heart failure. Pacing Clin Electrophysiol 2006;29:892904.

293. Wiegand UK, Bonnemeier H. [Heart rate variability preceding the onset of atrial fibrillation]. Herz 2001;26: 49-54.

294. Kuehl M, Stevens MJ. Cardiovascular autonomic neuropathies as complications of diabetes mellitus. Nat Rev Endocrinol 2012;8:405-416.

295. Assessment: Clinical autonomic testing report of the Therapeutics and Technology Assessment Subcommittee of the American Academy of Neurology. Neurology 1996; 46:873-880.

296. Vinik AI, Ziegler D. Diabetic cardiovascular autonomic neuropathy. Circulation 2007;115:387-397.

297. Grassi G. Debating sympathetic overactivity as a hallmark of human obesity: A pro's position. J Hypertens $1999 ; 17$ : 1059-1060.
298. Esler M, Straznicky N, Eikelis N, et al. Mechanisms of sympathetic activation in obesity-related hypertension. Hypertension 2006;48:787-796.

299. Chistiakov DA, Orekhov AN, Bobryshev YV. Cardiac extracellular vesicles in normal and infarcted heart. Int $J$ Mol Sci 2016;17:E63.

300. Sanz-Rubio D, Martin-Burriel I, Gil A, et al. Stability of circulating exosomal miRNAs in healthy subjects. Sci Rep 2018;8:10306.

301. $\mathrm{Hu} \mathrm{G}$, Drescher KM, Chen XM. Exosomal miRNAs: Biological properties and therapeutic potential. Front Genet 2012;3:56.

302. Dykes IM. Exosomes in cardiovascular medicine. Cardiol Ther 2017;6:225-237.

303. Zhou SS, Jin JP, Wang JQ, et al. miRNAS in cardiovascular diseases: Potential biomarkers, therapeutic targets and challenges. Acta Pharmacol Sin 2018;39:1073-1084.

304. Chen JF, Murchison EP, Tang R, et al. Targeted deletion of Dicer in the heart leads to dilated cardiomyopathy and heart failure. Proc Natl Acad Sci U S A 2008;105:21112116.

305. Kuwabara Y, Ono K, Horie T, et al. Increased microRNA1 and microRNA-133a levels in serum of patients with cardiovascular disease indicate myocardial damage. Circ Cardiovasc Genet 2011;4:446-454.

306. Li Q, Lin X, Yang X, et al. NFATc4 is negatively regulated in miR-133a-mediated cardiomyocyte hypertrophic repression. Am J Physiol Heart Circ Physiol 2010;298: H1340-H1347.

307. Mahoney LT, Burns TL, Stanford W, et al. Coronary risk factors measured in childhood and young adult life are associated with coronary artery calcification in young adults: The Muscatine Study. J Am Coll Cardiol 1996;27: 277-284.

308. Toprak A, Wang H, Chen W, et al. Relation of childhood risk factors to left ventricular hypertrophy (eccentric or concentric) in relatively young adulthood (from the Bogalusa Heart Study). Am J Cardiol 2008;101:1621-1625.

309. Juonala M, Magnussen CG, Venn A, et al. Influence of age on associations between childhood risk factors and carotid intima-media thickness in adulthood: The Cardiovascular Risk in Young Finns Study, the Childhood Determinants of Adult Health Study, the Bogalusa Heart Study, and the Muscatine Study for the International Childhood Cardiovascular Cohort (i3C) Consortium. Circulation 2010;122:2514-2520.

310. McGill HC, Jr., McMahan CA, Herderick EE, et al. Obesity accelerates the progression of coronary atherosclerosis in young men. Circulation 2002;105:2712-2718.

311. Biomarkers Definitions Working Group. Biomarkers and surrogate endpoints: Preferred definitions and conceptual framework. Clin Pharmacol Ther 2001;69:89-95.

Address correspondence to: Sushil K. Jain, PhD

Department of Pediatrics and Center for Cardiovascular Diseases and Sciences

Louisiana State University Health Sciences Center-Shreveport Shreveport, LA 71130

E-mail: sjain@1suhsc.edu 